\title{
SPEAKIng Up: A Model of Judicial Dissent AND DISCRETIONARY REVIEW
}

\author{
by
}

Andrew F. Daughety and Jennifer F. Reinganum

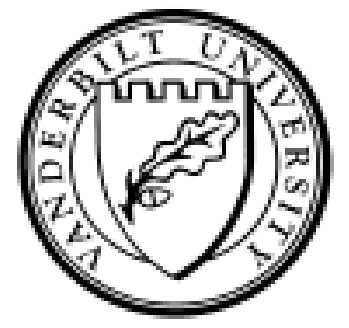

\section{Working Paper No. 02-W09R}

March 2002

Revised January 2003

\section{DEPARTMENT OF ECONOMICS \\ VANDERBILT UNIVERSITY \\ NASHVILLE, TN 37235}

www.vanderbilt.edu/econ 


\title{
Speaking Up: A Model of Judicial Dissent and Discretionary Review
}

\author{
Andrew F. Daughety* \\ Jennifer F. Reinganum* \\ Department of Economics \\ and Law School \\ Vanderbilt University \\ Nashville, TN 37235 \\ andrew.f.daughety@vanderbilt.edu \\ jennifer.f.reinganum@vanderbilt.edu
}

March 2002

Revised: January 2003

\begin{abstract}
* We thank the Law and Business Program at Vanderbilt University for financial support. We especially thank Lucian Bebchuk, Barry Friedman, Louis Kaplow, Nancy King, Richard Posner, Robert Rasmussen, Suzanna Sherry, Kathryn Spier and Christopher Yoo, as well as seminar participants at Harvard University and Vanderbilt University for helpful comments and suggestions on an earlier draft.
\end{abstract}




\title{
Speaking Up: A Model of Judicial Dissent and Discretionary Review
}

\author{
Andrew F. Daughety \\ Jennifer F. Reinganum
}

\begin{abstract}
We draw together concepts from political science, law, and economics to model discretionary actions by agents in a weak hierarchical system, wherein agents at a higher level need information from those at a lower level, but cannot directly reward or discipline those lower-level agents. In particular, we model the decision by an appeals court judge to communicate information to justices on a supreme court (via a written dissent) that a case is worthy of reconsideration, and discretionary decisions by justices on that supreme court to choose whether to formally review the case. In our model, judges and justices receive utility both from the outcome of the case in question and from the breadth of application of the outcome to jurisdictions besides the original source of the case (that is, the precedential value of the case). Action is costly for judges and for justices: for the appeals court judge, producing the dissenting opinion involves effort and may preclude being able to so promote other cases; for the justices on the supreme court, there are too many such cases to consider, so the decision to review a case implies foregone opportunities to review other cases through which they could also influence the evolution of the law. One very plausible equilibrium in our model predicts that an appeals court judge will find it valuable to communicate information to like-minded supreme court justices. However, a more unexpected type of equilibrium can exist that can best be summarized as an equilibrium with "strange bedfellows:" a judge with a particular ideological orientation may choose to communicate and influence a justice (or justices) with different ideological views in order to persuade the justice(s) to vote to review the case in question. Furthermore, we show that by setting a high hurdle for discretionary review (e.g., by restricting access), the supreme court justices can capitalize on the desire of appeals court judges to influence law, thereby encouraging enhanced informational effort by the appeals court judges: judges act as screeners of the cases most likely to be of interest to justices.
\end{abstract}




\section{Introduction}

We consider discretionary actions by agents in a weak hierarchical system, wherein agents at a higher level need information from those at a lower level, but cannot directly reward or discipline those lower-level agents. Examples of such organizations are systems of courts and advisory committees to larger bodies (such as congressional committees, faculty appointment committees and planning committees for large public projects). In particular, we develop a model in which judicial dissent at the appeals court level communicates information to justices on a supreme court that a case is worthy of reconsideration, either to correct a putative error or to establish a broader precedent.

We view judges and justices as (individually) motivated to influence the development of law as they (individually) regard to be correct; the salient attribute of a judge's dissent is the communication of important, otherwise unobservable, information about a case that might help ${ }^{1}$ a higher court justice pursue her own concept of how the law should evolve. Since, in equilibrium, review is (at least partially) contingent upon judicial dissent, the supreme court can capitalize on the desire of appeals court judges to influence the law, thereby encouraging enhanced information revelation by appeals court judges.

\section{$\underline{\text { Dissent }}$}

Dissent in a judicial system can be viewed as taking different forms. For example, when an appeals court in the U.S. (federal) system takes an appeal of a case previously decided by a trial

1 The notion that Supreme Court justices rely upon "cues" to guide their discretionary decision-making is an old one in the political science literature; see Tanenhaus, et.al. [1963]. Also see Perry [1991] and Epstein and Knight [1998] for reviews of some of the empirical findings on what cues the Supreme Court seems to use. 
court (a federal district court), the review is typically heard by three judges drawn from the pool of appeals court judges. ${ }^{2}$ Since majority rule is used to decide a case, sometimes a judge dissents from the majority and writes a discussion (a minority opinion) of his reasons for dissent. Such minority judges could choose to provide a perfunctory response, but they also might write so as to encourage a higher court to review the case and overturn the majority decision. ${ }^{3}$ They may wish to obtain a reversal limited to their own jurisdiction (perhaps they feel that the majority on the appeals court is in conflict with the rest of the system), or they may want to see both a reversal and the application of the resulting precedent to other jurisdictions. ${ }^{4}$ We assume that dissents written to encourage higher review are significantly different in nature (and the extent of effort expended) from more perfunctory minority opinions. ${ }^{5}$

A second form of dissent occurs when a majority on an appeals court panel adheres to a precedent, but indicates that they think the ruling precedent is wrong and should be changed. The

2 Pools of judges run from six, in the U.S. First Circuit Court of Appeals, to twenty-eight for the Ninth Circuit; there are twelve geographically-defined regions of the U.S. (each a "circuit") and one non-geographic circuit; see Cooter and Ulen [2000].

${ }^{3}$ For a current example, Judge Alex Kozinski's dissents on the U.S. Ninth Circuit Court of Appeals have been characterized by some of his colleagues as having exactly this purpose, and being rather successful at it; see Elias [2000]. Perry [1991], using a sample of cases appealed to the U.S. Supreme Court in 1976-1980, finds that cases involving a split at an Appeals Court are twice as likely to be granted review, as compared to cases involving a unanimous opinion (see p. 136, Table 5.1). Caldeira, Wright and Zorn [1999] find that Appeals Court dissents are statistically significant in influencing the granting of U.S. Supreme Court review.

4 There are a number of papers on what motivates judges and justices. See Posner [1993] for a discussion of the objective function for a judge or a justice.

${ }^{5}$ Posner [1993, p. 20], in discussing federal appeals courts, mentions "the current norm of explaining a dissenting vote rather than voting without explanation." Thus, we are particularly interested in the incremental effort associated with an enhanced dissent, one aimed at influencing at least some of the justices in the hierarchy above the dissenter, rather than simply explaining his actions. Norms in state courts vary widely; thus, a dissenting vote there may not be explained. 
majority is dissenting from established law but enforcing it nonetheless; it does this to encourage a higher authority to overrule it, thereby changing the law. An example of this form of dissent is Chief Judge Richard Posner's majority opinion in Khan v. State Oil Company [1996], wherein the majority followed standard procedure and applied existing precedent developed by the Supreme Court, but argued that the precedent was wrong, that it should be changed, and invited further appeal (i.e., to the U.S. Supreme Court) to make this so. ${ }^{6}$ A third form of dissent can arise when there is inter-circuit conflict; that is, when different circuits decide closely-related cases differently. ${ }^{7}$ More broadly, an opinion by a judge (or a collection of judges) that explicitly or implicitly encourages review for the purposes of reversal by a higher court can be a form of dissent from the existing body of law. In the formal analysis to follow we restrict ourselves to the first form discussed above.

Of course, the Supreme Court is not only influenced to take a case based on a dissent from the lower court. We consider the technical analysis of others' submissions, such as those by counsel for the parties themselves and interested third parties (all of which occur after the publication of the minority judge's dissent), to be similar to that which we provide below for the influence of the dissenting opinion itself. We further recognize that dissents written by an appeals court judge may also serve to influence courts in other circuits as well as judges in the circuit but not on the instant

${ }^{6}$ This is a maximum resale-price-maintenance case, which under a 1968 Supreme Court case (Albrecht v. Herald) was a per se violation of the Sherman Act. Based on the $7^{\text {th }}$ Circuit opinion, which simultaneously enforced the precedent and argued that the logic supporting Albrecht was "unsound when decided," the Supreme Court unanimously vacated and remanded Khan (and overruled Albrecht), requiring use by all courts of a rule-of-reason (i.e., did a defendant's conduct actually reduce competition?) when evaluating vertical maximum price fixing, the desired outcome argued by the $7^{\text {th }}$ Circuit opinion.

${ }^{7}$ Inter-circuit conflict is listed first, as a consideration for granting review of a case, under Rule 10 of "Rules of the Supreme Court of the United States," which govern procedure at the U.S. Supreme Court. See Epstein, et. al., [1996], p. 59. 
panel. We abstract from these other sources and audiences in the analysis and focus on the minority judge's choice to signal important information to the justices on a supreme court.

\section{$\underline{\text { Results }}$}

Our model generates a number of results. First, we find that sufficient restriction of access to a supreme court can yield increased information revelation about an appealed case, though excessive restriction can suppress information revelation. The basic intuition is straightforward: if all cases appealed to a supreme court will be reviewed, there is little incentive for a dissenting judge at an appeals court to spend much effort on communicating information, and the same is true if there is no chance for review. We investigate how various parameters influence the incentives to communicate information from a lower to a higher level, and why communicating may be productive from the dissenting judge's perspective. Particularly relevant parameters include opportunity costs, borne both by judges and justices, that reflect foregone chances to promote and review (respectively) other cases through which they could also influence the evolution of the law.

Second, we find conditions under which an appeals court judge will find it valuable to communicate information to like-minded supreme court justices: a minority judge chooses to write when his private information suggests a high likelihood of reversal by the supreme court, thereby acting as a screener of cases for these justices. Moreover, we show that a higher opportunity cost on the part of the justices generally implies a higher equilibrium threshold for a minority judge to write a dissenting opinion.

Third, a more unexpected type of equilibrium can exist that can best be summarized as an equilibrium with "strange bedfellows:" a judge with a particular ideological orientation may choose to communicate and influence a justice with different ideological views in order to persuade the 
justice to vote to review the case in question. This convergence of seemingly-opposed interests on the part of agents at different levels of the hierarchy is not a reflection of different priors over the ultimate outcome or errors in assessments, but instead arises because their largely-opposed interests can still generate a region of agreement. In this case, judges choose to write when their private information suggests an intermediate likelihood of reversal by the supreme court; we make this more precise below.

Fourth, we also characterize an equilibrium wherein no written dissent is needed for the higher court to choose to grant review of a lower court decision. This could reflect conditions when, for example, justices would choose to vote for review because generating a uniform precedent is more important to them than whether or not they are in the winning coalition on the issue. Thus, some behavior that would appear to be non-strategic is encompassed by our model.

\section{Plan of the Paper}

Section 2 provides a brief discussion of institutional background and a review of related literature, while Section 3 presents the elements of the model. Section 4 provides the payoff functions for the "active" agents (the minority judge on the appeals court and the justices on the supreme court). Section 5 characterizes the two types of pure-strategy equilibria in the model and Section 6 provides a summary of results and suggests potential extensions. Appendix A provides many of the proofs of the propositions while Appendix B provides supplementary material.

\section{Background, Associated Issues and Relevant Literature}

Most state and federal court systems in the U.S. are organized into three tiers. There is a lowest level of trial courts, were evidence is considered, facts are established, law is applied and 
decisions are made about who wins and who loses. Above that level are appeals courts, where issues of the appropriate interpretation of law in trial courts can be reviewed. Such courts usually have little or no discretionary power to decide whether a case that has been brought by a party will be reviewed, at least insofar as an initial review of a trial court's decision is concerned (generally, one review is a matter of right).

The exercise of discretion (choosing whether to review a case) is more typical of a "supreme" court. Especially in the federal system, the granting of a petition to the Supreme Court for a writ of certiorari (i.e., "granting cert") is rare, and has been declining steadily since the early 1970 's. In particular, the average yearly number of docketed cases granted cert was 225 in the 1970 's, 155 in the 1980 's, and 92 in the first half of the 1990's; these totals, respectively, represent $9.9 \%, 5.9 \%$ and $3.8 \%$ of the average number of docketed petitions for cert (Epstein, et. al, [1996], Tables 2-5 and 2-6). ${ }^{8}$ This reduction may have reflected many professional and personal reasons, but it does seem reasonable that the "cert budget" (a term we use to refer to the approximate number of cases that the Court will choose to hear in a year) is a decision variable, determined by some joint decision of the members of the Court. We do not intend to model the determination of the size of the cert budget itself in this paper, though we will manipulate the (exogenously determined) opportunity cost of hearing a case to simulate the effects of changes in the cert budget on the incentives for information transmission from a lower court judge; we presume that a higher opportunity cost of hearing a case reflects a tighter budget and a greater willingness to forego hearing some important cases.

${ }^{8}$ These numbers and percents exclude in forma pauperis applications (i.e., those who wish to be exempted from paying court costs), the volume of which has gone up significantly over time, but the number of which that are actually granted cert is quite small. 
In the political science literature, when a justice's decision to vote to grant or deny cert is influenced by considerations of the continuation game (that is, what might happen at a hearing on the case, how might the justices then vote, and what the breadth of the subsequent holding might be), ${ }^{9}$ such a justice is viewed as voting in a "strategic" or "sophisticated" manner (see Epstein and Knight [1998] and Caldeira, Wright and Zorn [1999] for recent contributions, including empirical analysis, to this issue). This is in contrast to the "attitudinal" approach (also known as "sincere" voting), wherein justices' votes reflect only their own immediate policy/ideological preferences. Our model assumes that judges and justices are forward-looking (and thus, engage in sophisticated behavior).

In the law and economics literature, models of appeal have typically taken an "errorcorrection" approach, though in some cases review is taken to be discretionary. For instance, Shavell [1995] and Daughety and Reinganum [2000] assume that the role of an appeals court is to correct lower court errors, where these errors are signaled by a litigant's decision to appeal. In Shavell's model, the error is of the mis-classification sort, while in Daughety and Reinganum's model, an appeals court determines error based on private information regarding what (it expects) the supreme court would do, were it to hear the case. Cameron, Segal and Sonder [2000] and Spitzer and Talley [2000] consider discretionary review by a higher court for the purpose of "ideological auditing." That is, the ideological preferences of the lower and higher court are known to differ. A lower court decision, which involves private information about the case, might not conform to the higher court's preferred decision were it also to observe the information; this is a source of error

${ }^{9}$ Schwartz [1992] proposes a non-cooperative voting model of this continuation game and considers justices with preferences over both the policy in question and the scope of the ruling. 
from the perspective of the higher court. Asymmetric information means that the lower court might indulge its ideological preferences; anticipating this, the higher court will "audit" the lower court's decisions, choosing some cases to review: the higher court will review the case, discover the lower court's private information and impose its preferred outcome. None of these models addresses the issue of making law by broadening precedent (in addition to error correction), the potential for detailed information provision through dissenting opinions (as opposed to simple votes), or the fact that each court involves multiple actors with various (and sometimes conflicting) preferences. ${ }^{10}$ These attributes are incorporated in the model we develop below, with novel results. For example, the equilibrium involving "strange bedfellows" would never arise if the supreme court justices were motivated only by error correction. Rather, this equilibrium stems directly from the presence of a coalition of justices who anticipate extending an appeals court ruling (with which they expect to agree) to other jurisdictions.

\section{Model Set-Up}

In this section we describe the basic elements of our hierarchical model, which is comprised of passive and active agents, outcomes (and utilities for those outcomes) for the active agents, common knowledge and private information about the likelihood of a case prevailing at the supreme court, justice-specific parameters summarizing justices' ideologies and the propensity for various

${ }^{10}$ Cross and Tiller [1998] argue that the presence of a potential dissenter on an appeals court panel (whose ideology differs from his colleagues' but agrees with that of the majority on the supreme court) can induce the appeals court majority to conform with supreme court precedent in cases where it would otherwise disregard it. They find that their hypothesis is supported by evidence from a study of appeals court opinions for the DC Circuit citing a particular U.S. Supreme Court precedent. Cross and Tiller focus on error correction but allow various and conflicting preferences. 
coalitions to form, and costs for writing opinions and for holding hearings.

$\underline{\text { Agents }}$

We consider seven agents, four of whom will be the primary focus of analysis: 1) a petitioner (P), who lost the case at the appeals court; 2) a respondent (R), who won the case at the appeals court; 3 ) justices of the supreme court (SC, here comprised of three justices, indexed by i, with $\mathrm{i}=1,2,3$ ), any one of whom, by voting to grant cert for P's case, can guarantee a hearing by the full supreme court (where a majority means at least two justices); 4) judges of an appeals court (AC, here comprised of two judges, with one labeled $\mathrm{M}$ and the other $\mathrm{m}$ ), where $\mathrm{M}$ denotes the majority judge (an aggregate of the judges who formed a majority and thereby determined the outcome of the case at $\mathrm{AC}$ ) and $\mathrm{m}$ denotes a minority judge (who voted in opposition to $\mathrm{M}$ in the case). For simplicity, we assume that $\mathrm{P}$ has a dominant strategy to appeal AC's decision and $\mathrm{R}$ has a dominant strategy to respond, should cert be granted. Also, we pick up the action at the point where a decision has been rendered at $\mathrm{AC}$ and $\mathrm{M}$ has written an opinion detailing the basis for the majority position at $\mathrm{AC}$, so the agents of particular interest in the analysis (the "active" agents) are the three justices and judge m; P, R and M are "passive" agents whose description is provided to give context for the active agents. We will refer to judge $m$ using male pronouns and to justices using female pronouns.

Note that the actual U.S. Supreme Court is comprised ${ }^{11}$ of nine justices, at least five of whom form a majority on a case, and at least four of whom had to vote for cert in order for the case

${ }^{11}$ We ignore the role of Supreme Court clerks, who expend significant effort helping justices filter cases for cert consideration (for example, see Perry [1991] or Epstein and Knight [1998] for details about the "cert pool" process). We assume these clerks are instructed by the justices and execute their responsibilities accordingly. 
to be heard. ${ }^{12}$ We simplify this to a three-justice panel, where one justice's vote is required to grant cert, and two justices are required for a majority. Thus, a justice voting for cert represents (in our model) a coalition of at least four justices on the Supreme Court (i.e., we abstract from the coalitionformation problem in cert voting). As in the U.S. Supreme Court, a justice voting for cert is not committed to being part of a majority to vote to reverse the lower court's ruling. Similarly, we have represented the essential aspects of the typical three-judge panel at an appeals court by a two-judge model, one of whom is decisive and determines the appeals court's decision.

Outcomes and Judicial Utility

The three justices, and judge $\mathrm{m}$, are assumed to care about both the eventual decision ${ }^{13}$ in a case and its precedential value (i.e., the breadth of applicability of this outcome to all jurisdictions). We address the relative importance of these two objectives below. We assume that judges and justices value having the final outcome be the one they prefer and having that outcome be applied system-wide. Since M found for R and $\mathrm{m}$ preferred $\mathrm{P}$, should cert be granted and $\mathrm{SC}$ find for $\mathrm{P}$, then the SC justices that form the majority (and judge $\mathrm{m}$ ) have obtained their best outcome, B, while any minority justice at SC has obtained her worst outcome, W. Alternatively, if cert is granted and SC finds for R, then the SC justices that form the majority obtain their best outcome (B), while $\mathrm{m}$ and any minority justice obtain their worst outcome (W). If cert is not granted, then m obtains an intermediate outcome (for convenience we will refer to it as m's second-worst outcome, denoted

${ }^{12}$ See Perry [1991] and Epstein and Knight [1998] about the "Rule-of-Four"wherein at least four votes are generally required to grant cert.

${ }^{13}$ For convenience we refer to a decision for $\mathrm{P}$ or for R. However, we do not assume that justices and judges necessarily, literally, care which litigant wins; rather, a decision reflects an interpretation of the law about which each justice has a jurisprudential philosophy. 
SW), since denial of cert means that the decision made by M stands, but is limited to that circuit.

If cert is not granted, however, justices obtain their second best (SB) or their second worst (SW) outcome, depending upon whether they would have been in the majority or the minority if cert had been granted. A justice who would have been part of a minority (had the case been heard) obtains her second best outcome if she would have preferred $\mathrm{R}$ to $\mathrm{P}$ or her second worst outcome if she would have preferred $\mathrm{P}$ to $\mathrm{R}$, since in either case $\mathrm{R}$ has won and the precedential value is limited to the circuit. Similarly, a justice who would have been part of a majority (had the case been heard) obtains her second best outcome if she would have preferred R to P or her second worst outcome if she would have preferred P to R.

In keeping with the above, for any justice, and for judge $\mathrm{m}$, we denote the utilities of the outcomes by $\mathrm{u}^{\mathrm{B}}, \mathrm{u}^{\mathrm{SB}}, \mathrm{u}^{\mathrm{SW}}, \mathrm{u}^{\mathrm{W}}$, and thus we treat all three justices (and judge $\mathrm{m}$ ) as identical in terms of the utilities of outcomes (differentiation will enter the analysis via justice-specific parameters to be described below). ${ }^{14}$ Strict preference over all outcomes means that $\mathrm{u}^{\mathrm{B}}>\mathrm{u}^{\mathrm{SB}}>\mathrm{u}^{\mathrm{SW}}>\mathrm{u}^{\mathrm{W}}$; this ordering will be assumed for most of the analysis. If the primary issue is whether the lower court is perceived as possibly being out-of-step with previous decisions of the supreme court (or the question is simply whether $\mathrm{P}$ or $\mathrm{R}$ actually wins), then $\mathrm{u}^{\mathrm{B}}=\mathrm{u}^{\mathrm{SB}}>\mathrm{u}^{\mathrm{SW}}=\mathrm{u}^{\mathrm{W}}$. In this special case, all that matters is whether AC's ruling is left standing or is reversed: this is the case of pure error correction. ${ }^{15}$ On the other hand, if $\mathrm{u}^{\mathrm{B}}>\mathrm{u}^{\mathrm{SB}}=\mathrm{u}^{\mathrm{SW}}>\mathrm{u}^{\mathrm{W}}$, then what matters is the breadth of the

${ }^{14}$ This assumption is for simplicity of exposition alone, since no agent's utility is compared with that of any other agent. If one wanted to distinguish the utility levels for different agents, one could simply subscript them with $i=1,2,3$ and $\mathrm{m}$.

${ }^{15}$ As an example, think of AC as the Florida Supreme Court and the case as Bush v. Gore, 2000. The Supreme Court's majority argued that their decision only concerned the case at hand, that settling who won the election via the court was essential, that their decision had no precedential 
decision and how it creates a precedent applicable to all circuits. ${ }^{16}$ Here the emphasis is on creating a desired alignment of the circuits more than bringing a particular circuit into an existing alignment. $^{17}$

Probability Assessments, Private Information and Common Knowledge

When AC hears the case, $\mathrm{M}$ and $\mathrm{m}$ observe information which is not captured in the record. By this we don't mean unrecorded facts, but rather potentially important issues and ideas about law and public policy that are, or might be, influenced by aspects of this case. We think of AC judges as considerably more than either scribes or ideologues: they bring their human capital to bear on matters they hear, organizing issues and recognizing important facts and related legal principles. We formalize this by assuming that $M$ and $m$ each receive private signals ( $p_{M}$ and $p_{m}$, respectively) about the likelihood that P will win at SC if cert is granted and P's case is heard (this likelihood is denoted $\mathrm{p}_{\mathrm{SC}}$ ). We assume that the probabilities $\mathrm{p}_{\mathrm{M}}, \mathrm{p}_{\mathrm{m}}$, and $\mathrm{p}_{\mathrm{SC}}$ are affiliated random variables (see

value, and that it was to correct what it deemed a conflict between the Florida Court's action and federal law. In other words, what mattered was the case at hand and bringing the lower court into alignment with what the Supreme Court majority conceived of as existing law.

${ }^{16}$ Admittedly, some Supreme Court decisions are not fully implemented by all lower courts, since some may resist the new precedent. Even if implementation is not complete, $\mathrm{u}^{\mathrm{B}}>\mathrm{u}^{\mathrm{SB}}$.

17 For example, in Eastern Enterprises v. Apfel, 1998, the majority of the Supreme Court supported limiting economic regulation by the Congress when it was particularly retroactive. This case was the sixth of similar cases concerning the Coal Act, all occurring in different circuits, all being decided in the same direction by the appeals courts. It was the fourth of these cases to be appealed to the Supreme Court and the only one granted cert (see Daughety and Reinganum, [1999]). The Supreme Court's decision found a critical clause of the Coal Act unconstitutional, reversed the First Circuit's decision and called into question the decisions made in the other five circuits, and provided new standards for future appeals courts' decisions concerning economic regulation. 
Milgrom and Weber [1982]), and that the justices do not learn $\mathrm{p}_{\mathrm{SC}}$ until after the cert decision. ${ }^{18}$ Affiliation means that both $\mathrm{p}_{\mathrm{M}}$ and $\mathrm{p}_{\mathrm{m}}$ are informative for each justice in estimating $\mathrm{p}_{\mathrm{SC}}$; each justice estimates $\mathrm{p}_{\mathrm{SC}}$ by employing the prior joint density $\mathrm{h}\left(\mathrm{p}_{\mathrm{M}}, \mathrm{p}_{\mathrm{m}}, \mathrm{p}_{\mathrm{SC}}\right)$ and any information revealed by $\mathrm{M}$ and $\mathrm{m}$.

Private information learned by $\mathrm{M}$ and $\mathrm{m}$ is revealed via judges writing opinions (we assume that a judge's written opinion truthfully reveals his private information). ${ }^{19}$ We further assume that $\mathrm{M}$ must write a full and complete opinion (and thus, $\mathrm{p}_{\mathrm{M}}$ will be revealed) while $\mathrm{m}$ can choose between writing a more perfunctory opinion (which we refer to as "no opinion" 20 ) or one aimed at influencing the supreme court (revealing $\left.\mathrm{p}_{\mathrm{m}}\right)$. To capture this, the pair of reports $\mathrm{s}_{\mathrm{AC}}=\left(\mathrm{s}_{\mathrm{M}}, \mathrm{s}_{\mathrm{m}}\right)$ is either $\left(\mathrm{p}_{\mathrm{M}}, \mathrm{p}_{\mathrm{m}}\right)$ or $\left(\mathrm{p}_{\mathrm{M}}, \varnothing\right)$, where the first version indicates that both judges wrote opinions while the second version means that $\mathrm{m}$ provided no opinion. Finally, we assume that $\mathrm{m}$ knows $\mathrm{p}_{\mathrm{M}}$ (reads M's opinion) before he chooses to write a promotional or perfunctory opinion.

Thus, we think of P's appeal for a grant of certiorari as consisting purely ${ }^{21}$ of $\mathrm{s}_{\mathrm{AC}}$; based on

18 Thus, perhaps oral arguments reveal $\mathrm{p}_{\mathrm{SC}}$ to the justices. This approach formally avoids the need to model the hearing or subsequent voting in detail which, while a desirable extension, is beyond the scope of the current paper and is a subject of future research.

19 Judges and justices in the federal system are appointed for life and we assume that the repeated game aspects of such interactions encourage truthful revelation. One might also think that individual ideological considerations might color the revelation of a signal; we abstract from this (allowing for such "honest filtering" is possible, but unnecessarily complicates the current analysis).

20 "No opinion" here is shorthand for opinions written only for the local record and not aimed at promoting a case to the Supreme Court; see the earlier discussion in footnote 5 above. That is, minority opinions here are either directed at being dissents that argue for review or they are not.

${ }^{21}$ Thus, as mentioned earlier, we abstract from added arguments by P and R, amicus curiae briefs, etc., all of which add to the information that may influence SC to grant cert, but all of which would be produced after $m$ has written an opinion or has chosen to provide no opinion. Much of the analysis in this paper could be extended to these other sources of influence on the cert decision, but this needlessly complicates the exposition. 
this and knowledge of $\mathrm{h}$, each justice can form: 1) her beliefs $\mathrm{b}\left(\mathrm{p}_{\mathrm{M}}, \mathrm{s}_{\mathrm{m}}\right)$ about $\mathrm{p}_{\mathrm{m}}$; and 2) her posterior estimate of $\mathrm{p}_{\mathrm{SC}}$, which we denote as $\rho\left(\mathrm{p}_{\mathrm{M}}, \mathrm{b}\left(\mathrm{p}_{\mathrm{M}}, \mathrm{s}_{\mathrm{m}}\right)\right){ }^{22}$ If $\mathrm{m}$ writes an opinion, then $\mathrm{s}_{\mathrm{m}}=$ $\mathrm{p}_{\mathrm{m}}$ and, therefore, $\mathrm{b}\left(\mathrm{p}_{\mathrm{M}}, \mathrm{s}_{\mathrm{m}}\right)=\mathrm{p}_{\mathrm{m}}$. When $\mathrm{m}$ writes no opinion, then $\mathrm{s}_{\mathrm{m}}=\varnothing$, meaning that $\mathrm{b}\left(\mathrm{p}_{\mathrm{M}}, \varnothing\right)$ is a set of possible $\mathrm{p}_{\mathrm{m}}$-values for which the justices believe judge $\mathrm{m}$ would choose to write no opinion; this set will be described in more detail in the analysis section but it is the same for all justices, since $\mathrm{h}(\bullet, \bullet, \bullet), \mathrm{p}_{\mathrm{M}}$, and $\mathrm{s}_{\mathrm{m}}$ are all common knowledge. Since $\rho\left(\mathrm{p}_{\mathrm{M}}, \mathrm{p}_{\mathrm{m}}\right)$ is the expected value of $\mathrm{p}_{\mathrm{SC}}$ given $\mathrm{p}_{\mathrm{M}}$ and $\mathrm{p}_{\mathrm{m}}$, a consequence of affiliation is that $\rho\left(\mathrm{p}_{\mathrm{M}}, \mathrm{p}_{\mathrm{m}}\right)$ is non-decreasing in both of its arguments (see Milgrom and Weber [1982], Theorem 5); for the sequel we assume that $\rho\left(\mathrm{p}_{\mathrm{M}}, \mathrm{p}_{\mathrm{m}}\right)$ is strictly increasing in both of its arguments.

$\underline{\text { Justice-Specific Parameters }}$

We will assume that when justices vote on cert they anticipate the likelihood that, should SC take the case and find for P (respectively, R), various possible coalitions of justices will form a majority for P (respectively, R); in particular, each justice must forecast the likelihood that she would be in the majority coalition supporting the supreme court's decision (if cert were granted and the case heard). This likelihood reflects both ideological/jurisprudential considerations as well as the tendency for the justice to be part of a majority. By ideology we do not mean (simply) political affiliation; rather we view judges and justices as having jurisprudential perspectives that differ, which we refer to as "ideology." Since we join the analysis after the vote at AC, m's ideological preferences are unimportant in our analysis (they are already captured in his vote).

Let $\alpha_{\mathrm{i}}^{\mathrm{P}}$ denote the probability that justice $\mathrm{i}$ will belong to a majority finding for $\mathrm{P}$, given that cert was granted and $\mathrm{P}$ will win at $\mathrm{SC}$ (that is, at least two justices out of the three vote for $\mathrm{P}$ after

22 Technical details for constructing $\rho\left(\mathrm{p}_{\mathrm{M}}, \mathrm{b}\left(\mathrm{p}_{\mathrm{M}}, \mathrm{s}_{\mathrm{m}}\right)\right)$ are provided in Appendix $\mathrm{B}$. 
a hearing on P's case). Similarly, let $\alpha_{i}^{R}$ denote the probability that justice i will be part of a majority for $\mathrm{R}$, given that $\mathrm{R}$ will win at the supreme court if the case is heard; these parameters can be constructed from more primitive measures. ${ }^{23}$ Hence, the pair $\left(\alpha_{\mathrm{i}}^{\mathrm{P}}, \alpha_{\mathrm{i}}^{\mathrm{R}}\right)$ summarizes both ideological and coalitional considerations for justice i. For example, if $\left(\alpha_{i}^{\mathrm{P}}, \alpha_{\mathrm{i}}^{\mathrm{R}}\right)=(1,0)$, then we would think of justice $\mathrm{i}$ as a "pure pro-P" justice, who strongly expects to be in the majority should $\mathrm{P}$ win, and in the minority should $R$ win, at the supreme court. Similarly, if $\left(\alpha_{\mathrm{i}}^{\mathrm{P}}, \alpha_{\mathrm{i}}^{\mathrm{R}}\right)=(0,1)$ then justice $\mathrm{i}$ is "pure pro-R." If $\left(\alpha_{\mathrm{i}}^{\mathrm{P}}, \alpha_{\mathrm{i}}^{\mathrm{R}}\right)=(1,1)$ then we think of justice $\mathrm{i}$ as strongly expecting to be in the majority no matter which way the decision might go; we'll call such a justice a "pure majoritarian" justice. Alternatively, if $\left(\alpha_{\mathrm{i}}^{\mathrm{P}}, \alpha_{\mathrm{i}}^{\mathrm{R}}\right)=(0,0)$, then the justice is a "pure contrarian" (she never expects to be in the majority no matter which litigant wins; note that this cannot hold simultaneously for all three justices, since it would preclude a majority outcome).

\section{$\underline{\text { Judicial Costs }}$}

We incorporate two costs. Judge $\mathrm{m}$ incurs a cost $\mathrm{k}_{\mathrm{AC}}>0$ if he chooses to write an opinion intended to promote interest by SC; thus, this is both an effort cost and an opportunity cost. ${ }^{24}$ Of course, some AC judges use clerks more extensively than others to draft opinions for them, but this means there is still an allocation issue, since the preferences of a judge will make the management

${ }^{23}$ Let $\beta_{i j}^{P}=\operatorname{Pr}\{i$ and $j$ alone form a majority $\mid P$ wins $\}$, for $i \neq j, i, j=1,2,3$, and let $\beta_{123}^{P}$ be the probability that (given $\mathrm{P}$ wins), there is a unanimous decision. Note that these conditional probabilities sum to one: $\beta_{12}^{\mathrm{P}}+\beta_{12}^{\mathrm{P}}+\beta_{23}^{\mathrm{P}}+\beta_{123}^{\mathrm{P}}=1$. There is a similar set of probabilities for $\mathrm{R}$, namely the $\beta_{\mathrm{ij}}^{\mathrm{R}}$ (for $\mathrm{i} \neq \mathrm{j}, \mathrm{i}, \mathrm{j}=1,2,3$ ) and $\beta_{123}^{\mathrm{R}}$, similarly summing to one since they are conditional on R winning. Thus, $\alpha_{\mathrm{i}}^{\mathrm{P}} \equiv \beta_{\mathrm{ij}}^{\mathrm{P}}+\beta_{\mathrm{ik}}^{\mathrm{P}}+\beta_{123}^{\mathrm{P}}$. From this definition, $\alpha_{1}^{\mathrm{P}}+\alpha_{2}^{\mathrm{P}}+\alpha_{3}^{\mathrm{P}}=2+\beta_{123}^{\mathrm{P}}$ and $\alpha_{1}^{\mathrm{R}}+$ $\alpha_{2}^{\mathrm{R}}+\alpha_{3}^{\mathrm{R}}=\beta_{123}^{\mathrm{R}}+2$, so $2 \leq \alpha_{1}^{\mathrm{n}}+\alpha_{2}^{\mathrm{n}}+\alpha_{3}^{\mathrm{n}} \leq 3$, for $\mathrm{n}=\mathrm{P}$, R. For a discussion of empirical regularities in the formation of majority coalitions at the U.S. Supreme Court, see Edelman and Sherry [2000].

${ }^{24}$ One might even speculate that this cost is zero or negative, if a judge views opinionwriting as an investment, possibly in his being picked as a justice someday. We abstract from such considerations in this paper. 
and execution of an opinion written to influence SC more worthy of control and individual effort than those opinions being provided simply for the record. Thus, it is reasonable to think of judge $\mathrm{m}$ facing an effort cost. It is also an opportunity cost in the sense that judge $\mathrm{m}$ might have devoted this effort to promoting another case for review.

Each justice anticipates a cost of $\mathrm{k}_{\mathrm{SC}}$ should cert be granted for a case. This cost reflects not only the obvious imposition of actually having a hearing (rather than playing golf, etc.), but more importantly, the opportunity cost of not having considered some other case that the justice could have used to make or clarify law. We will not model SC's determination of the cert budget (which is, presumably, a somewhat "soft" constraint), but will allow (at certain points) $\mathrm{k}_{\mathrm{SC}}$ to be a policy

lever reflecting the choice by $\mathrm{SC}$ to consider only a small number of cases. Both $\mathrm{k}_{\mathrm{AC}}$ and $\mathrm{k}_{\mathrm{SC}}$ are common knowledge; we consider some implications of weakening this assumption at the end of Section 5 and in Section 6.

\section{Payoff Functions for Supreme Court Justices and for Judge m} $\underline{\text { Justice } \mathrm{i}}$

In deciding whether or not to vote for cert, justice i compares the ex ante expected utility from granting cert, net of $\mathrm{k}_{\mathrm{SC}}$, to the ex ante expected utility from denying cert, based on all available information at the time (i.e., prior information, such as $\mathrm{h}$ and $\left(\alpha_{\mathrm{i}}^{\mathrm{P}}, \alpha_{\mathrm{i}}^{\mathrm{R}}\right)$, plus the appeals court opinions). Let $\pi_{\mathrm{i}}\left(\mathrm{C}, \mathrm{s}_{\mathrm{AC}}\right)$ denote justice i's ex ante expected utility should cert be granted, given the vector $\mathrm{s}_{\mathrm{AC}}$ of appeals court opinions. Then

$$
\begin{aligned}
\pi_{\mathrm{i}}\left(\mathrm{C}, \mathrm{s}_{\mathrm{AC}}\right)= & \rho\left(\mathrm{p}_{\mathrm{M}}, \mathrm{b}\left(\mathrm{p}_{\mathrm{M}}, \mathrm{s}_{\mathrm{m}}\right)\right)\left[\alpha_{\mathrm{i}}^{\mathrm{P}} \mathrm{u}^{\mathrm{B}}+\left(1-\alpha_{\mathrm{i}}^{\mathrm{P}}\right) \mathrm{u}^{\mathrm{W}}\right] \\
& +\left(1-\rho\left(\mathrm{p}_{\mathrm{M}}, \mathrm{b}\left(\mathrm{p}_{\mathrm{M}}, \mathrm{s}_{\mathrm{m}}\right)\right)\right)\left[\alpha_{\mathrm{i}}^{\mathrm{R}} \mathrm{u}^{\mathrm{B}}+\left(1-\alpha_{\mathrm{i}}^{\mathrm{R}}\right) \mathrm{u}^{\mathrm{W}}\right]-\mathrm{k}_{\mathrm{SC}} .
\end{aligned}
$$


This expression is interpreted as follows: upon observing $\mathrm{s}_{\mathrm{AC}}=\left(\mathrm{p}_{\mathrm{M}}, \mathrm{s}_{\mathrm{m}}\right)$, justice $\mathrm{i}$ believes that with probability $\rho\left(\mathrm{p}_{\mathrm{M}}, \mathrm{b}\left(\mathrm{p}_{\mathrm{M}}, \mathrm{s}_{\mathrm{m}}\right)\right)$ the supreme court will find in favor of $\mathrm{P}$, should it grant cert and hear the case. Conditional on a finding for $\mathrm{P}$, justice i expects to be in the majority with probability $\alpha_{i}^{P}$ (and thus anticipates the highest possible utility, $\mathrm{u}^{\mathrm{B}}$ ) and in the minority with probability $1-\alpha_{\mathrm{i}}^{\mathrm{P}}$ (and thus anticipates the lowest possible utility, $\mathrm{u}^{\mathrm{w}}$ ). On the other hand, justice $\mathrm{i}$ believes that with probability $1-\rho\left(p_{M}, b\left(p_{M}, s_{m}\right)\right)$ the supreme court will find in favor of $R$, should it review the case. Conditional on a finding for $\mathrm{R}$, justice i expects to be in the majority with probability $\alpha_{\mathrm{i}}^{\mathrm{R}}$ (and thus anticipates the highest possible utility, $\mathrm{u}^{\mathrm{B}}$ ) and in the minority with probability $1-\alpha_{i}^{\mathrm{R}}$ (and thus anticipates the lowest possible utility, $\mathrm{u}^{\mathrm{w}}$ ). In either event, hearing the case and coming to a decision (negotiating, voting, etc.) costs justice $\mathrm{i}$ the amount $\mathrm{k}_{\mathrm{SC}}$.

If cert is denied, then the appeals court's ruling stands, but it constitutes a precedent only within that circuit. Let $\pi_{\mathrm{i}}\left(\mathrm{NC}, \mathrm{s}_{\mathrm{AC}}\right)$ denote justice i's ex ante expected utility should cert be denied, given the vector $\mathrm{s}_{\mathrm{AC}}$ of appeals court opinions. Then

$$
\begin{aligned}
\pi_{i}\left(N C, s_{A C}\right)=\rho\left(p_{M}, b\right. & \left.\left(p_{M}, s_{m}\right)\right)\left[\alpha_{i}^{P} u^{S W}+\left(1-\alpha_{i}^{P}\right) u^{S B}\right] \\
& +\left(1-\rho\left(p_{M}, b\left(p_{M}, s_{m}\right)\right)\right)\left[\alpha_{i}^{R} u^{S B}+\left(1-\alpha_{i}^{R}\right) u^{S W}\right] .
\end{aligned}
$$

This expression is interpreted as follows: upon observing $\mathrm{s}_{\mathrm{AC}}=\left(\mathrm{p}_{\mathrm{M}}, \mathrm{s}_{\mathrm{m}}\right)$, justice $\mathrm{i}$ believes that with probability $\rho\left(\mathrm{p}_{\mathrm{M}}, \mathrm{b}\left(\mathrm{p}_{\mathrm{M}}, \mathrm{s}_{\mathrm{m}}\right)\right)$ the supreme court would have found in favor of $\mathrm{P}$, had it chosen to review the case. Conditional on a finding for $\mathrm{P}$, justice $\mathrm{i}$ expects that she would have been in the majority with probability $\alpha_{\mathrm{i}}^{\mathrm{P}}$ (and thus anticipates the second-worst possible utility, $\mathrm{u}^{\mathrm{SW}}$, because when the case is denied cert, the outcome remains the appeals court's ruling in favor of R, but at least the associated precedent is confined to the circuit) and in the minority with probability $1-\alpha_{i}^{P}$ (and thus anticipates the second-best possible utility, $\mathrm{u}^{\mathrm{SB}}$, because although the justice agrees with 
the appeals court, the ruling constitutes precedent only within the circuit, and it would have been applicable across all circuits had the supreme court reviewed the case). On the other hand, justice i believes that with probability $1-\rho\left(p_{M}, b\left(p_{M}, s_{m}\right)\right)$ the supreme court would have found in favor of $\mathrm{R}$, had it chosen to review the case. Conditional on a finding for $\mathrm{R}$, justice $\mathrm{i}$ expects that she would have been in the majority with probability $\alpha_{i}^{R}$ (and thus anticipates the second-highest possible utility, $\mathrm{u}^{\mathrm{SB}}$, for reasons explained above) and in the minority with probability $1-\alpha_{\mathrm{i}}^{\mathrm{R}}$ (and thus anticipates the second-lowest possible utility, $\mathrm{u}^{\mathrm{Sw}}$, again for reasons explained above).

Justice $i$ is willing to vote to grant cert if and only if $\pi_{i}\left(C, s_{A C}\right) \geq \pi_{i}\left(N C, s_{A C}\right)$. That is:

$$
\mathrm{V}_{\mathrm{i}}\left(\mathrm{p}_{\mathrm{M}}, \mathrm{b}\left(\mathrm{p}_{\mathrm{M}}, \mathrm{s}_{\mathrm{m}}\right)\right) \equiv \rho\left(\mathrm{p}_{\mathrm{M}}, \mathrm{b}\left(\mathrm{p}_{\mathrm{M}}, \mathrm{s}_{\mathrm{m}}\right)\right)\left(\gamma_{\mathrm{i}}^{\mathrm{P}}-\gamma_{\mathrm{i}}^{\mathrm{R}}\right)+\gamma_{\mathrm{i}}^{\mathrm{R}}-\mathrm{k}_{\mathrm{SC}} \geq 0
$$

where $\gamma_{i}^{\mathrm{P}}=\alpha_{i}^{\mathrm{P}}\left(\mathrm{u}^{\mathrm{B}}-\mathrm{u}^{\mathrm{SW}}\right)+\left(1-\alpha_{i}^{\mathrm{P}}\right)\left(\mathrm{u}^{\mathrm{W}}-\mathrm{u}^{\mathrm{SB}}\right)$ and $\gamma_{i}^{\mathrm{R}}=\alpha_{i}^{\mathrm{R}}\left(\mathrm{u}^{\mathrm{B}}-\mathrm{u}^{\mathrm{SB}}\right)+\left(1-\alpha_{\mathrm{i}}^{\mathrm{R}}\right)\left(\mathrm{u}^{\mathrm{W}}-\mathrm{u}^{\mathrm{SW}}\right)$. The expression $V_{i}\left(p_{M}, b\left(p_{M}, s_{m}\right)\right)$ represents the net payoff for justice $i$ if cert is granted rather than denied. Thus, justice $\mathrm{i}$ will vote to grant cert if this expression is positive, will vote to deny cert if it is negative and will be indifferent if this expression is zero. A fact that will be used repeatedly is that:

$$
\mathrm{V}_{\mathrm{i}}\left(\mathrm{p}_{\mathrm{M}}, \mathrm{b}\left(\mathrm{p}_{\mathrm{M}}, \mathrm{s}_{\mathrm{m}}\right)\right)=\mathrm{E}\left\{\mathrm{V}_{\mathrm{i}}\left(\mathrm{p}_{\mathrm{M}}, \mathrm{p}_{\mathrm{m}}\right) \mid \mathrm{p}_{\mathrm{m}} \in \mathrm{b}\left(\mathrm{p}_{\mathrm{M}}, \mathrm{s}_{\mathrm{m}}\right)\right\}
$$

where the expectation is taken over $\mathrm{p}_{\mathrm{m}}$ conditional on $\mathrm{p}_{\mathrm{M}}$.

\section{$\underline{\text { Judge } m}$}

Judge $\mathrm{m}$ is willing to write an opinion (thereby revealing $\mathrm{p}_{\mathrm{m}}$ ), if doing so would provoke cert, whenever:

$$
\rho\left(p_{M}, p_{m}\right) u^{B}+\left[1-\rho\left(p_{M}, p_{m}\right)\right] u^{W}-k_{A C} \geq u^{S W}
$$

The first term on the left-hand-side of this expression is judge m's posterior estimate of $\mathrm{p}_{\mathrm{SC}}$ times the utility of judge m's best outcome (a finding for P, reversing the appeals court in this circuit and 
establishing a precedent for all circuits). Of course, with the complementary probability, SC may generate judge m's worst outcome (affirming the appeals court in this circuit and establishing a precedent for all circuits); the second term on the left-hand-side reflects this consideration. The third term is judge m's effort cost, $\mathrm{k}_{\mathrm{AC}}$. Finally, the right-hand-side is simply judge m's utility if cert is denied; the current ruling prevails, but only at the level of this circuit, resulting in a utility of $\mathrm{u}^{\mathrm{SW}}$.

Thus, judge $\mathrm{m}$ is willing to write an opinion, if it would provoke cert, whenever his net payoff, $\mathrm{V}_{\mathrm{m}}\left(\mathrm{p}_{\mathrm{M}}, \mathrm{p}_{\mathrm{m}}\right) \equiv \rho\left(\mathrm{p}_{\mathrm{M}}, \mathrm{p}_{\mathrm{m}}\right) \mathrm{u}^{\mathrm{B}}+\left[1-\rho\left(\mathrm{p}_{\mathrm{M}}, \mathrm{p}_{\mathrm{m}}\right)\right] \mathrm{u}^{\mathrm{W}}-\mathrm{k}_{\mathrm{AC}}-\mathrm{u}^{\mathrm{SW}}$, is non-negative; judge $\mathrm{m}$ is unwilling to write an opinion, even if it would provoke cert, if $\mathrm{V}_{\mathrm{m}}\left(\mathrm{p}_{\mathrm{M}}, \mathrm{p}_{\mathrm{m}}\right)<0$. The function $\mathrm{V}_{\mathrm{m}}\left(\mathrm{p}_{\mathrm{M}}, \mathrm{p}_{\mathrm{m}}\right) \geq 0$ whenever:

$$
\rho\left(p_{M}, p_{m}\right) \geq\left[u^{S W}-u^{W}+k_{A C}\right] /\left[u^{B}-u^{W}\right]
$$

If $\mathrm{u}^{\mathrm{SW}}-\mathrm{u}^{\mathrm{W}}+\mathrm{k}^{\mathrm{AC}}<\mathrm{u}^{\mathrm{B}}-\mathrm{u}^{\mathrm{W}}$, then the right-hand-side above (which is positive) is less than 1 .

On the other hand, judge $\mathrm{m}$ is willing to expend effort $\mathrm{k}_{\mathrm{AC}}$ to prevent cert if and only if $\mathrm{u}^{\mathrm{SW}}$ $\mathrm{k}_{\mathrm{AC}} \geq \rho\left(\mathrm{p}_{\mathrm{M}}, \mathrm{p}_{\mathrm{m}}\right) \mathrm{u}^{\mathrm{B}}+\left[1-\rho\left(\mathrm{p}_{\mathrm{M}}, \mathrm{p}_{\mathrm{m}}\right)\right] \mathrm{u}^{\mathrm{W}}$; that is, if and only if:

$$
\rho\left(p_{\mathrm{M}}, \mathrm{p}_{\mathrm{m}}\right) \leq\left[\mathrm{u}^{\mathrm{SW}}-\mathrm{u}^{\mathrm{W}}-\mathrm{k}_{\mathrm{AC}}\right] /\left[\mathrm{u}^{\mathrm{B}}-\mathrm{u}^{\mathrm{W}}\right]
$$

The right-hand-side above is always less than 1 , and is positive as long as $\mathrm{u}^{\mathrm{SW}}-\mathrm{u}^{\mathrm{W}}-\mathrm{k}_{\mathrm{AC}}>0$. For the remainder of the paper we will focus on dissenting opinions written to provoke, not prevent, cert; this is captured in the following assumption.

Assumption 1. $\mathrm{u}^{\mathrm{SW}}-\mathrm{u}^{\mathrm{W}}<\mathrm{k}_{\mathrm{AC}}<\mathrm{u}^{\mathrm{B}}-\mathrm{u}^{\mathrm{SW}}$.

That is, writing a dissent is sufficiently costly that judge m would never make the effort simply in order to prevent cert, but writing a dissent is not too costly to pursue in order to provoke cert. Sympathetic, Unsympathetic, Predisposed and Persuadable Justices

Given that judge $\mathrm{m}$ has written an opinion, justice i's net payoff becomes: 


$$
\mathrm{V}_{\mathrm{i}}\left(\mathrm{p}_{\mathrm{M}}, \mathrm{p}_{\mathrm{m}}\right)=\rho\left(\mathrm{p}_{\mathrm{M}}, \mathrm{p}_{\mathrm{m}}\right)\left(\gamma_{\mathrm{i}}^{\mathrm{P}}-\gamma_{\mathrm{i}}^{\mathrm{R}}\right)+\gamma_{\mathrm{i}}^{\mathrm{R}}-\mathrm{k}_{\mathrm{SC}} \text {. }
$$

Notice that (assuming that $\gamma_{i}^{\mathrm{P}} \neq \gamma_{\mathrm{i}}^{\mathrm{R}}$ ) the function $\mathrm{V}_{\mathrm{i}}\left(\mathrm{p}_{\mathrm{M}}, \mathrm{p}_{\mathrm{m}}\right)$ is monotone in $\mathrm{p}_{\mathrm{m}}$, since $\rho\left(\mathrm{p}_{\mathrm{M}}, \mathrm{p}_{\mathrm{m}}\right)$ is increasing in $\mathrm{p}_{\mathrm{m}} ; \mathrm{V}_{\mathrm{i}}\left(\mathrm{p}_{\mathrm{M}}, \mathrm{p}_{\mathrm{m}}\right)$ is increasing in $\mathrm{p}_{\mathrm{m}}$ if $\gamma_{\mathrm{i}}^{\mathrm{P}}>\gamma_{\mathrm{i}}^{\mathrm{R}}$ and decreasing in $\mathrm{p}_{\mathrm{m}}$ if $\gamma_{\mathrm{i}}^{\mathrm{P}}<\gamma_{\mathrm{i}}^{\mathrm{R}}$.

Definition 1. Justice $i$ is sympathetic to judge m's point of view regarding cert if $V_{i}\left(p_{M}, p_{m}\right)$ is increasing in $\mathrm{p}_{\mathrm{m}}$. Justice $\mathrm{i}$ is unsympathetic to judge m's point of view regarding cert if $\mathrm{V}_{\mathrm{i}}\left(\mathrm{p}_{\mathrm{M}}, \mathrm{p}_{\mathrm{m}}\right)$ is decreasing in $\mathrm{p}_{\mathrm{m}}$.

Since $V_{m}\left(p_{M}, p_{m}\right)$ is increasing in $p_{m}$, a sympathetic justice's preferences concerning granting cert are aligned (though not necessarily perfectly) with those of judge m, while an unsympathetic justice's preferences regarding granting cert are inversely aligned with those of judge $\mathrm{m}$.

Figure 1 below illustrates how the space of $\left(\alpha_{i}^{\mathrm{P}}, \alpha_{\mathrm{i}}^{\mathrm{R}}\right)$-pairs for justice $\mathrm{i}$ is subdivided into

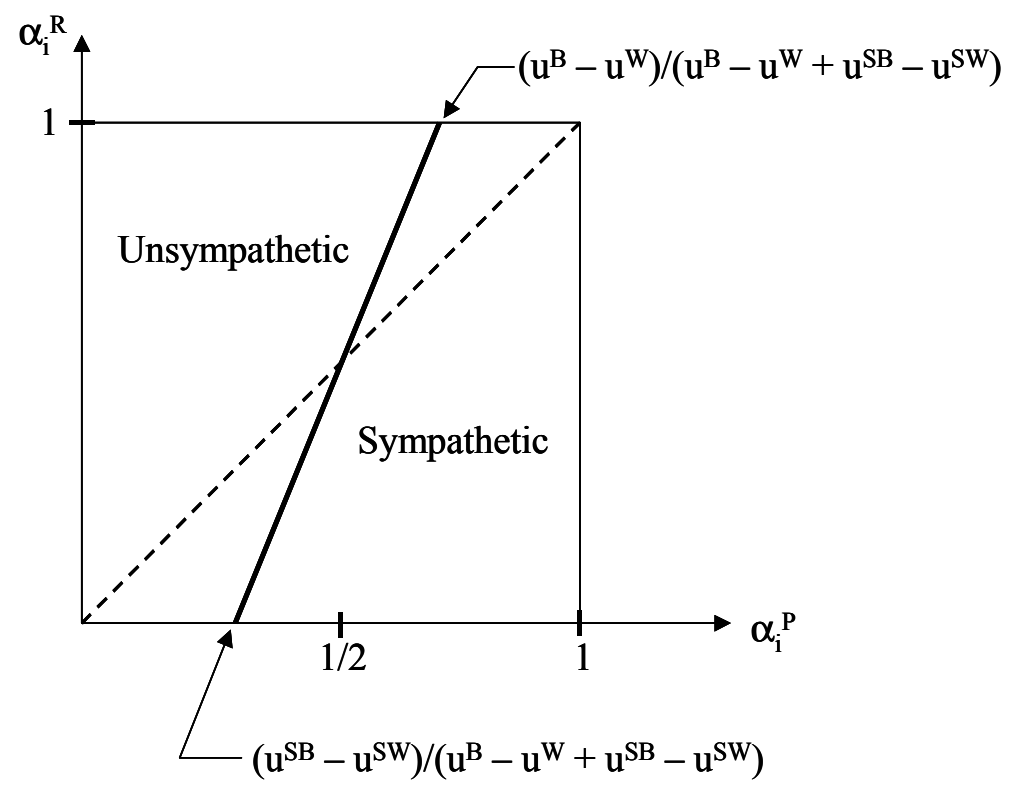

Figure 1: Sympathetic and Unsympathetic Regions for Justice i

sympathetic and unsympathetic regions. At one end of the dashed $45^{\circ}$-line is a pure contrarian justice (i.e., $(0,0))$ while at the other end is a pure majoritarian justice (i.e., $(1,1))$. The dark, upward- 
sloping line represents “neutral" sympathy (i.e., $\gamma_{i}^{\mathrm{P}}=\gamma_{i}^{\mathrm{R}}$ ); it intersects the $45^{\circ}$-line at $\alpha_{i}^{\mathrm{P}}=\alpha_{i}^{\mathrm{R}}=1 / 2$, the $\alpha_{i}^{\mathrm{P}}$-axis at $\left(\mathrm{u}^{\mathrm{SB}}-\mathrm{u}^{\mathrm{SW}}\right) /\left(\mathrm{u}^{\mathrm{B}}-\mathrm{u}^{\mathrm{W}}+\mathrm{u}^{\mathrm{SB}}-\mathrm{u}^{\mathrm{SW}}\right)$ and the top of the $[0,1] \times[0,1]$ box $\left(\right.$ where $\left.\alpha_{i}^{\mathrm{R}}=1\right)$ at $\alpha_{i}^{\mathrm{P}}=\left(\mathrm{u}^{\mathrm{B}}-\mathrm{u}^{\mathrm{W}}\right) /\left(\mathrm{u}^{\mathrm{B}}-\mathrm{u}^{\mathrm{W}}+\mathrm{u}^{\mathrm{SB}}-\mathrm{u}^{\mathrm{SW}}\right)$. Left of the neutral sympathy line are combinations of $\alpha_{\mathrm{i}}^{\mathrm{P}}$ and $\alpha_{i}^{R}$ such that justice $i$ is unsympathetic; to the right are combinations such that justice $i$ is sympathetic.

The foregoing analysis assumed that $\mathrm{u}^{\mathrm{B}}>\mathrm{u}^{\mathrm{SB}}>\mathrm{u}^{\mathrm{SW}}>\mathrm{u}^{\mathrm{W}}$. Recall the two special (extreme) configurations of utilities raised in Section 3, namely: 1) $\mathrm{u}^{\mathrm{B}}=\mathrm{u}^{\mathrm{SB}}>\mathrm{u}^{\mathrm{SW}}=\mathrm{u}^{\mathrm{W}}$ and 2) $\mathrm{u}^{\mathrm{B}}>\mathrm{u}^{\mathrm{SB}}=\mathrm{u}^{\mathrm{SW}}$ $>u^{\mathrm{w}}$. The first configuration was identified with cases wherein the primary concern might be bringing a circuit "back into line" (pure error correction) with supreme court perceptions of existing law. The foregoing figure makes clear that, for this configuration of utilities, the neutral sympathy line is vertical at $\alpha_{\mathrm{i}}^{\mathrm{P}}=1 / 2$, so sympathy requires simply that $\alpha_{\mathrm{i}}^{\mathrm{P}}>1 / 2$ for some justice.

Alternatively, the second configuration above was identified with cases wherein the primary concern was the payoff from extending the outcome from the $\mathrm{AC}$ in question to all other jurisdictions. In this case the neutral sympathy line is the $45^{\circ}$-line, so sympathy towards granting cert is reinforced by stronger ideological preference (towards $\mathrm{P}$ ).

Definition 2. Justice $\mathrm{i}$ is persuadable regarding cert if $\mathrm{V}_{\mathrm{i}}\left(\mathrm{p}_{\mathrm{M}}, 0\right)$ and $\mathrm{V}_{\mathrm{i}}\left(\mathrm{p}_{\mathrm{M}}, 1\right)$ are of opposite sign. Justice $i$ is predisposed to grant cert if $\mathrm{V}_{\mathrm{i}}\left(\mathrm{p}_{\mathrm{M}}, \mathrm{p}_{\mathrm{m}}\right) \geq 0$ for all $\mathrm{p}_{\mathrm{m}}$ and is predisposed to deny cert if $\mathrm{V}_{\mathrm{i}}\left(\mathrm{p}_{\mathrm{M}}, \mathrm{p}_{\mathrm{m}}\right) \leq 0$ for all $\mathrm{p}_{\mathrm{m}}$.

If justice $i$ is persuadable, then there exists a critical value of $p_{m}, x_{i} \in(0,1)$, such that $\mathrm{V}_{\mathrm{i}}\left(\mathrm{p}_{\mathrm{M}}, \mathrm{x}_{\mathrm{i}}\right)=0$. This means that there is a (non-degenerate) set of values of $\mathrm{p}_{\mathrm{m}}$ that judge $\mathrm{m}$ expects would result in justice i voting to grant cert, and a (non-degenerate) set of values of $\mathrm{p}_{\mathrm{m}}$ that judge $\mathrm{m}$ expects would result in justice $\mathrm{i}$ voting to deny cert. On the other hand, if justice $\mathrm{i}$ is predisposed 
(either to grant, or to deny, cert), then no such critical value exists in $(0,1)$.

For a sympathetic and persuadable justice $i$, the function $V_{i}\left(p_{M}, p_{m}\right)$ is increasing in $p_{m}$ and justice $\mathrm{i}$ : 1) will vote to grant cert if a dissenting opinion reports $\mathrm{p}_{\mathrm{m}} \in\left(\mathrm{x}_{\mathrm{i}}, 1\right]$; 2$)$ will vote to deny cert if a dissenting opinion reports $\mathrm{p}_{\mathrm{m}} \in\left[0, \mathrm{x}_{\mathrm{i}}\right)$; and 3) is indifferent for $\mathrm{p}_{\mathrm{m}}=\mathrm{x}_{\mathrm{i}}$. For an unsympathetic and persuadable justice $i$, the function $V_{i}\left(p_{M}, p_{m}\right)$ is decreasing in $p_{m}$ and justice $i$ : 1) will vote to grant cert if a dissenting opinion reports $\mathrm{p}_{\mathrm{m}} \in\left[0, \mathrm{x}_{\mathrm{i}}\right) ; 2$ ) will vote to deny cert if a dissenting opinion reports $\mathrm{p}_{\mathrm{m}} \in\left(\mathrm{x}_{\mathrm{i}}, 1\right]$; and 3$)$ is indifferent for $\mathrm{p}_{\mathrm{m}}=\mathrm{x}_{\mathrm{i}}$.

\section{Equilibrium Analysis}

In the remainder of the paper we focus on circumstances involving at least one persuadable justice, since those who are predisposed will vote predictably in one direction, independent of what might be revealed in judge m's dissenting opinion. Moreover, we focus on cases in which no justice is predisposed to grant cert; otherwise, there is no analysis to be done as cert is guaranteed. We consider three possible compositions for SC: a) one or more justices are sympathetic and persuadable and all the rest are predisposed to deny cert; b) one or more justices are unsympathetic and persuadable and all the rest are predisposed to deny cert; c) both sympathetic and unsympathetic persuadable justices are present.

Our results are summarized by two types of equilibria, one type wherein judge m never writes an opinion (Type I) and one type wherein judge $\mathrm{m}$ writes an opinion only if his private information is in a specific subset of $[0,1]$ (Type II or "writing" equilibria, denoted below as IIa, IIb and IIc, reflecting the three compositions listed above). The Type I equilibrium can be defined in the same way for any composition of the supreme court, while details of the Type II equilibria 
vary with the court's composition. We summarize the Type I equilibrium immediately below and then proceed to the composition-specific analyses.

Definition 3. Type I Equilibrium: Judge m doesn’t write a dissenting opinion for any $\mathrm{p}_{\mathrm{m}}$. At least one justice votes to grant cert without a dissenting opinion.

This is straightforward to verify: if at least one justice votes to grant cert without an opinion, then judge $\mathrm{m}$ will never write one since he never writes an opinion to prevent cert (by Assumption 1) and need not write one to provoke cert. This type of equilibrium exists if and only if at least one justice finds it optimal to vote to grant cert when judge m never writes an opinion; that is, if and only if:

$$
\max _{\mathrm{i}}\left\{\mathrm{V}_{\mathrm{i}}\left(\mathrm{p}_{\mathrm{M}},[0,1]\right)\right\}=\max _{\mathrm{i}}\left\{\mathrm{E}\left\{\mathrm{V}_{\mathrm{i}}\left(\mathrm{p}_{\mathrm{M}}, \mathrm{p}_{\mathrm{m}}\right) \mid \mathrm{p}_{\mathrm{m}} \in[0,1]\right\}\right\} \geq 0
$$

For example, this inequality is likely to hold if $\mathrm{u}^{\mathrm{B}}$ and $\mathrm{u}^{\mathrm{W}}$ are both large compared with $\mathrm{k}_{\mathrm{SC}}$. Then, though not predisposed, justice i will vote to grant cert even without a dissent from judge m, simply because the expected value of a decision by the supreme court sufficiently exceeds the cost of review. ${ }^{25}$

$\underline{\text { Writing Equilibrium With Sympathetic and Persuadable Justices }}$

Assume that the court is composed of one sympathetic and persuadable justice $i$, and two justices who are predisposed to deny cert (and who thus vote to deny cert independent of judge m's behavior). We develop the intuition for this case and then state the proposition which characterizes writing-equilibrium behavior for the case of multiple sympathetic and persuadable justices.

A candidate for a pure-strategy writing equilibrium involves judge $\mathrm{m}$ writing an opinion for

${ }^{25}$ It might be that some issues are so important to justice $i$ that she would rather see them settled by the supreme court (even if contrary to her own view) than left standing as decided by the court below. For such an issue, the second best outcome would be for the case to be decided by the supreme court, with justice $i$ in the minority. 
relatively high values of $\mathrm{p}_{\mathrm{m}}$ and justice $\mathrm{i}$ voting to grant cert if and only if judge $\mathrm{m}$ writes an opinion; we will call this a Type IIa equilibrium. Recall that $\mathrm{V}_{\mathrm{m}}\left(\mathrm{p}_{\mathrm{M}}, \mathrm{p}_{\mathrm{m}}\right)$ is the net expected value to judge m of writing a dissenting opinion, if doing so would provoke cert. Thus, the point $\mathrm{x}_{\mathrm{m}}$ at which judge $m$ is just indifferent is given by $V_{m}\left(p_{M}, x_{m}\right)=0$ (where we assume $x_{m} \in(0,1)$ so that judge $m$ is not predisposed to always write or to never write). For $\mathrm{p}_{\mathrm{m}} \in\left[0, \mathrm{x}_{\mathrm{m}}\right)$, judge $\mathrm{m}$ is unwilling to write even if doing so would provoke cert; for $\mathrm{p}_{\mathrm{m}} \in\left(\mathrm{x}_{\mathrm{m}}, 1\right]$, judge $\mathrm{m}$ is willing to write if doing so would provoke cert; finally, for $\mathrm{p}_{\mathrm{m}}=\mathrm{x}_{\mathrm{m}}$, judge $\mathrm{m}$ is indifferent about writing a dissenting opinion if doing so would provoke cert. Figure 2 below illustrates $\mathrm{V}_{\mathrm{m}}$ and $\mathrm{V}_{\mathrm{i}}\left(\right.$ and $\mathrm{x}_{\mathrm{m}}$ and $\mathrm{x}_{\mathrm{i}}$, respectively; lines are

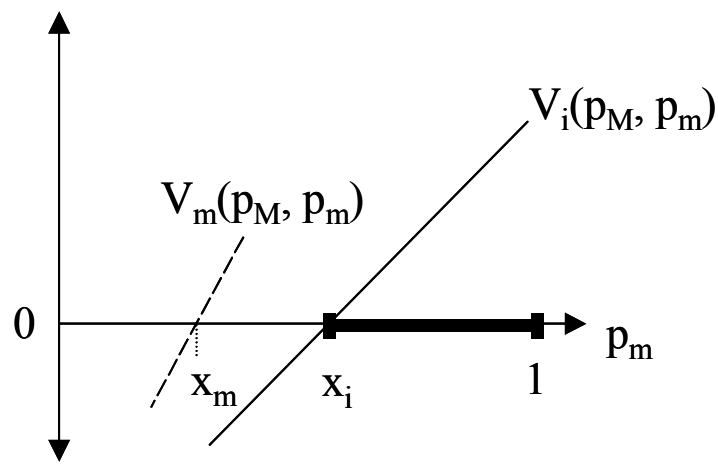

(a) $x_{m} \leq x_{i}$

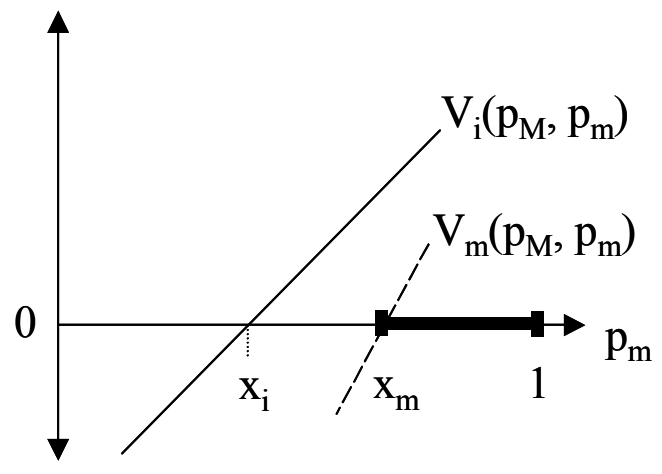

(b) $x_{m}>x_{i}$

\section{Figure 2: $\mathrm{V}_{\mathrm{i}}, \mathrm{V}_{\mathrm{m}}$ and Type IIa Equilibria}

used for simplicity of illustration) for the case where justice $\mathrm{i}$ is sympathetic and persuadable. Figure 2(a) illustrates the case wherein $x_{m} \leq x_{i}$ while Figure 2(b) illustrates the case wherein $x_{m}>$ $x_{i}$. The equilibrium set of $p_{m}$-values for which judge $m$ writes an opinion is darkened for emphasis.

First consider case (a), wherein $x_{m} \leq x_{i}$. If $x_{m}<x_{i}$, then there is an interval $\left[x_{m}, x_{i}\right)$ of values of $p_{m}$ for which judge $m$ would be willing to write an opinion in order to provoke cert, but these 
values of $p_{m}$ would result in justice i voting to deny cert: even though judge $m$ is willing to write for $\mathrm{p}_{\mathrm{m}} \in\left[\mathrm{x}_{\mathrm{m}}, \mathrm{x}_{\mathrm{i}}\right.$ ), it would be counter-productive to do so. Thus, for $\mathrm{x}_{\mathrm{m}} \leq \mathrm{x}_{\mathrm{i}}$, judge $\mathrm{m}$ would only be willing to write an opinion for $\mathrm{p}_{\mathrm{m}} \in\left[\mathrm{x}_{\mathrm{i}}, 1\right]$, if it would provoke cert; since $\mathrm{V}_{\mathrm{i}}\left(\mathrm{p}_{\mathrm{M}}, \mathrm{p}_{\mathrm{m}}\right) \geq 0$ for all $\mathrm{p}_{\mathrm{m}}$ $\in\left[\mathrm{x}_{\mathrm{i}}, 1\right]$, justice $\mathrm{i}$ would be willing to vote for cert upon receiving such an opinion (this is the darkened interval illustrated in Figure 2(a)). Now consider case (b), wherein $x_{m}>x_{i}$. Judge $m$ would be willing to write an opinion for $\mathrm{p}_{\mathrm{m}} \in\left[\mathrm{x}_{\mathrm{m}}, 1\right]$, if it would provoke cert; moreover, justice $\mathrm{i}$ would vote to grant cert upon receiving such an opinion because $V_{i}\left(p_{M}, p_{m}\right)>0$ for all $p_{m} \in\left(x_{i}, 1\right]$. Since $x_{m}>x_{i}$, judge $m$ writes when $p_{m} \in\left[x_{m}, 1\right]$ (this is the darkened interval in Figure 2(b)).

Combining these results suggests the form of a Type IIa equilibrium: judge m writes an opinion if and only if $\mathrm{p}_{\mathrm{m}} \in\left[\max \left\{\mathrm{x}_{\mathrm{m}}, \mathrm{x}_{\mathrm{i}}\right\}, 1\right] .{ }^{26}$ Moreover, judge $\mathrm{m}$ would write only if it is necessary to provoke cert; that is, only if cert would be denied absent a dissenting opinion. This type of equilibrium can exist if and only if it is optimal for justice i to vote to deny cert following the receipt of no opinion, when judge $\mathrm{m}$ writes an opinion only for $\mathrm{p}_{\mathrm{m}} \in\left[\max \left\{\mathrm{x}_{\mathrm{m}}, \mathrm{x}_{\mathrm{i}}\right\}, 1\right]$; that is, if and only if $\mathrm{V}_{\mathrm{i}}\left(\mathrm{p}_{\mathrm{M}},\left[0, \max \left\{\mathrm{x}_{\mathrm{m}}, \mathrm{x}_{\mathrm{i}}\right\}\right)\right)=\mathrm{E}\left\{\mathrm{V}_{\mathrm{i}}\left(\mathrm{p}_{\mathrm{M}}, \mathrm{p}_{\mathrm{m}}\right) \mid \mathrm{p}_{\mathrm{m}} \in\left[0, \max \left\{\mathrm{x}_{\mathrm{m}}, \mathrm{x}_{\mathrm{i}}\right\}\right)\right\} \leq 0$

Note that judge $\mathrm{m}$ will never write an opinion for $\mathrm{p}_{\mathrm{m}} \in\left[0, \max \left\{\mathrm{x}_{\mathrm{m}}, \mathrm{x}_{\mathrm{i}}\right\}\right)$, since writing is either too costly or would not have a beneficial effect from judge m's point of view; thus, upon receiving no dissenting opinion, justice i must include this interval in her posterior beliefs. This

${ }^{26}$ A mild form of multiple equilibria arises here in the sense that the assignment of the leftmost point in the interval (to the writing versus non-writing set) is arbitrary: there is another writing equilibrium in which $\mathrm{p}_{\mathrm{m}} \in\left(\max \left\{\mathrm{x}_{\mathrm{m}}, \mathrm{x}_{\mathrm{i}}\right\}, 1\right]$. To see why, observe that if $\mathrm{x}_{\mathrm{m}} \leq \mathrm{x}_{\mathrm{i}}$, then judge $\mathrm{m}$ will write (will be indifferent about writing) an opinion when $\mathrm{p}_{\mathrm{m}}=\mathrm{x}_{\mathrm{i}}>\mathrm{x}_{\mathrm{m}}\left(\mathrm{p}_{\mathrm{m}}=\mathrm{x}_{\mathrm{i}}=\mathrm{x}_{\mathrm{m}}\right)$ if he thinks an indifferent justice $i$ will vote to grant cert; and judge $m$ won't write an opinion when $p_{m}=x_{i} \geq x_{m}$ if he thinks an indifferent justice $i$ will vote to deny cert. Similarly, if $x_{m}>x_{i}$, then judge $m$ is indifferent about writing when $\mathrm{p}_{\mathrm{m}}=\mathrm{x}_{\mathrm{m}}$ even though it would provoke cert. We ignore this inessential multiplicity in what follows. 
interval is the smallest set of $\mathrm{p}_{\mathrm{m}}$-values for which judge $\mathrm{m}$ would not write an opinion, and it provides the basis for a Type IIa equilibrium. In contrast, the interval $[0,1]$ is the largest set of $\mathrm{p}_{\mathrm{m}}{ }^{-}$ values that justice $\mathrm{i}$ could include in her posterior beliefs following the receipt of no opinion, and it provides the basis for a Type I equilibrium. There are no other types of pure-strategy equilibria (except as noted in footnote 26).

The arguments above generalize straightforwardly to the case of one to three sympathetic and persuadable justices (indexed by i), again assuming that any remaining justices are predisposed to deny cert. Let $\mathrm{x}^{\mathrm{S}} \equiv \min _{\mathrm{i}}\left\{\mathrm{x}_{\mathrm{i}}\right\}$ and define a Type IIa equilibrium as follows.

Definition 4. Type IIa Equilibrium: Judge $\mathrm{m}$ writes a dissenting opinion if and only if $\mathrm{p}_{\mathrm{m}}$ $\in\left[\max \left\{\mathrm{x}_{\mathrm{m}}, \mathrm{x}^{\mathrm{S}}\right\}, 1\right] ;$ at least one justice votes to grant cert upon receipt of such an opinion. All justices vote to deny cert without a dissenting opinion.

We summarize the conditions under which each type of equilibrium exists in the following proposition; the proof is sketched below (the complete proof is in Appendix A).

Proposition 1. There are only two possible types of pure-strategy equilibrium for the case of one to three sympathetic and persuadable justices, assuming that any remaining justices are predisposed to deny cert; at least one pure-strategy equilibrium exists.

(a) If $\max _{\mathrm{i}}\left\{\mathrm{E}\left\{\mathrm{V}_{\mathrm{i}}\left(\mathrm{p}_{\mathrm{M}}, \mathrm{p}_{\mathrm{m}}\right) \mid \mathrm{p}_{\mathrm{m}} \in\left[0, \max \left\{\mathrm{x}_{\mathrm{m}}, \mathrm{x}^{\mathrm{S}}\right\}\right)\right\}\right\}>0$, then only a Type I equilibrium exists.

(b) If $\max _{\mathrm{i}}\left\{\mathrm{E}\left\{\mathrm{V}_{\mathrm{i}}\left(\mathrm{p}_{\mathrm{M}}, \mathrm{p}_{\mathrm{m}}\right) \mid \mathrm{p}_{\mathrm{m}} \in[0,1]\right\}\right\}<0$, then only a Type IIa equilibrium exists.

(c) If $\max _{\mathrm{i}}\left\{\mathrm{E}\left\{\mathrm{V}_{\mathrm{i}}\left(\mathrm{p}_{\mathrm{M}}, \mathrm{p}_{\mathrm{m}}\right) \mid \mathrm{p}_{\mathrm{m}} \in\left[0, \max \left\{\mathrm{x}_{\mathrm{m}}, \mathrm{x}^{\mathrm{S}}\right\}\right)\right\}\right\} \leq 0$ and

$\max _{\mathrm{i}}\left\{\mathrm{E}\left\{\mathrm{V}_{\mathrm{i}}\left(\mathrm{p}_{\mathrm{M}}, \mathrm{p}_{\mathrm{m}}\right) \mid \mathrm{p}_{\mathrm{m}} \in[0,1]\right\}\right\} \geq 0$, then both Type I and Type IIa equilibria exist.

Note that parts (a) and (b) express conditions that exclude one type of equilibrium. Thus, 
when the hypothesis of part (a) holds, then some justice will vote to grant cert, without an opinion, under the belief that $\mathrm{p}_{\mathrm{m}} \in\left[0, \max \left\{\mathrm{x}_{\mathrm{m}}, \mathrm{x}^{\mathrm{S}}\right\}\right)$, thereby upsetting a Type IIa equilibrium. When the hypothesis of part (b) holds, then no justice will vote to grant cert under the belief that $\mathrm{p}_{\mathrm{m}} \in[0,1]$, upsetting a Type I equilibrium.

In Proposition 2 below, we summarize the comparative statics effects of the majority opinion $\mathrm{p}_{\mathrm{M}}$ and the parameters $\mathrm{u}^{\mathrm{B}}, \mathrm{u}^{\mathrm{SB}}, \mathrm{u}^{\mathrm{SW}}, \mathrm{u}^{\mathrm{W}}, \mathrm{k}_{\mathrm{AC}}, \mathrm{k}_{\mathrm{SC}}, \alpha_{\mathrm{i}}^{\mathrm{P}}$ and $\alpha_{\mathrm{i}}^{\mathrm{R}}$ on the critical values $\mathrm{x}_{\mathrm{m}}$ and $\mathrm{x}_{\mathrm{i}}{ }^{27}$ Details of the proof can be found in Appendix B.

\section{Proposition 2.}

(a) The critical value $\mathrm{x}_{\mathrm{m}}$ is an increasing function of $\mathrm{u}^{\mathrm{SW}}$ and $\mathrm{k}_{\mathrm{AC}}$, and a decreasing function of $\mathrm{p}_{\mathrm{M}}, \mathrm{u}^{\mathrm{B}}$ and $\mathrm{u}^{\mathrm{W}}$; it is independent of $\mathrm{u}^{\mathrm{SB}}, \mathrm{k}_{\mathrm{SC}}, \alpha_{\mathrm{i}}^{\mathrm{P}}$ and $\alpha_{\mathrm{i}}^{\mathrm{R}}$.

(b) The critical value $\mathrm{x}_{\mathrm{i}}$ is an increasing function of $\mathrm{u}^{\mathrm{SB}}, \mathrm{u}^{\mathrm{SW}}$, and $\mathrm{k}_{\mathrm{SC}}$, and $\mathrm{a}$ decreasing function of $\mathrm{p}_{\mathrm{M}}, \mathrm{u}^{\mathrm{B}}, \mathrm{u}^{\mathrm{W}}, \alpha_{\mathrm{i}}^{\mathrm{P}}$ and $\alpha_{\mathrm{i}}^{\mathrm{R}}$; it is independent of $\mathrm{k}_{\mathrm{AC}}$.

Proposition 2(a) deals with the willingness of judge $m$ to write a dissenting opinion (if doing so would provoke cert), and states that judge $\mathrm{m}$ would be willing to write an opinion for a larger set $\left[\mathrm{x}_{\mathrm{m}}, 1\right]$ of realizations of $\mathrm{p}_{\mathrm{m}}$ if $\mathrm{p}_{\mathrm{M}}, \mathrm{u}^{\mathrm{B}}$ or $\mathrm{u}^{\mathrm{W}}$ were higher, or if $\mathrm{u}^{\mathrm{SW}}$ or $\mathrm{k}_{\mathrm{AC}}$ were lower. Thus, $\mathrm{p}_{\mathrm{M}}$ and $\mathrm{p}_{\mathrm{m}}$ are complementary in the sense that a higher value of $\mathrm{p}_{\mathrm{M}}$ increases the value to judge $\mathrm{m}$ of writing an opinion. A higher value of $u^{\mathrm{B}}$ increases the up-side potential of writing to provoke cert, while an increase in $\mathrm{u}^{\mathrm{W}}$ reduces the down-side risk of writing to provoke cert, and thus both of these promote dissent. An increase in $\mathrm{u}^{\mathrm{SW}}$, which is the status quo outcome for judge $\mathrm{m}$, discourages dissent, as does an increase in $\mathrm{k}_{\mathrm{AC}}$, judge $\mathrm{m}$ 's perceived cost of writing an opinion. Proposition 2(b)

${ }^{27}$ Recall that, if one distinguished utility values for judge $\mathrm{m}$ from those of each justice, then 2(a) below refers to judge m's utility values and 2(b) below refers to justice i's utility values, and these need not be the same. 
deals with justice i's willingness to vote to grant cert (having received an opinion reporting $\mathrm{p}_{\mathrm{m}}$ ) and states that justice $i$ will be willing to vote to grant cert for a larger set $\left[\mathrm{x}_{\mathrm{i}}, 1\right]$ of realizations of $\mathrm{p}_{\mathrm{m}}$ if $\mathrm{p}_{\mathrm{M}}, \mathrm{u}^{\mathrm{B}}, \mathrm{u}^{\mathrm{W}}, \alpha_{\mathrm{i}}^{\mathrm{P}}$ or $\alpha_{\mathrm{i}}^{\mathrm{R}}$ were higher, or if $\mathrm{u}^{\mathrm{SB}}, \mathrm{u}^{\mathrm{SW}}$, or $\mathrm{k}_{\mathrm{SC}}$ were lower. Again, $\mathrm{p}_{\mathrm{M}}$ and $\mathrm{p}_{\mathrm{m}}$ are complementary in the sense that a higher value of $p_{M}$ increases the value to justice $i$ of voting to grant cert (recall that justice $\mathrm{i}$ is sympathetic). A higher value of $\mathrm{u}^{\mathrm{B}}, \alpha_{\mathrm{i}}^{\mathrm{P}}$ or $\alpha_{\mathrm{i}}^{\mathrm{R}}$ increases the up-side potential of granting cert, since justice i receives $\mathrm{u}^{\mathrm{B}}$ whenever she is in the majority after the case is heard by the supreme court, and $\alpha_{\mathrm{i}}^{\mathrm{P}}$ and $\alpha_{\mathrm{i}}^{\mathrm{R}}$ denote these probabilities (conditional on $\mathrm{P}$ or $\mathrm{R}$ winning, respectively). A higher value of $\mathrm{u}^{\mathrm{W}}$ reduces the down-side risk of granting cert, since it is received whenever justice $i$ is in the minority after the case is heard by the supreme court. The utilities $\mathrm{u}^{\mathrm{SB}}$ and $\mathrm{u}^{\mathrm{SW}}$ apply should the case not be granted cert, depending on whether justice $\mathrm{i}$ would have been in the majority or the minority, respectively, had the case been heard by the supreme court. Higher values of these utilities make justice i less willing to vote to grant cert, as does a higher value of $\mathrm{k}_{\mathrm{SC}}$, thus requiring a higher minimum realization of $\mathrm{p}_{\mathrm{m}}$ in order to convince justice i to vote to grant cert.

Since the critical value in a Type IIa equilibrium is $\max \left\{\mathrm{x}_{\mathrm{m}}, \mathrm{x}^{\mathrm{s}}\right\}$, this critical value inherits the same local comparative statics as the critical value that defines it (i.e., $\mathrm{x}_{\mathrm{m}}$ or $\mathrm{x}_{\mathrm{i}}$, for some i). However, more substantial parameter changes may cause regime changes between the regimes described in Proposition 1.

A particularly interesting effect arises as $\mathrm{k}_{\mathrm{SC}}$ increases; for simplicity, we revert to the case of one sympathetic and persuadable justice i to discuss this global comparative static effect, though this is readily extended to the case of multiple sympathetic and persuadable justices. Recall that the critical value $\mathrm{x}_{\mathrm{m}}$ does not depend on $\mathrm{k}_{\mathrm{SC}}$, while the critical value $\mathrm{x}_{\mathrm{i}}$ is an increasing function of $\mathrm{k}_{\mathrm{SC}}$ 
(see Proposition 2). To illustrate the full range of possible equilibrium behavior, we consider a justice who is (just barely) predisposed to grant cert when $\mathrm{k}_{\mathrm{SC}}=0$, and is (just barely) predisposed to deny cert at a finite, but sufficiently large $\mathrm{k}_{\mathrm{SC}}$. That is, $\mathrm{x}_{\mathrm{i}}(0)=0$ and let $\mathrm{k}_{\mathrm{SC} 3}$ be defined by $\mathrm{x}_{\mathrm{i}}\left(\mathrm{k}_{\mathrm{SC} 3}\right)$ $=1$. Then for all $\mathrm{k}_{\mathrm{SC}} \in\left(0, \mathrm{k}_{\mathrm{SC} 3}\right)$, justice $\mathrm{i}$ is persuadable and hence $\mathrm{x}_{\mathrm{i}}\left(\mathrm{k}_{\mathrm{SC}}\right) \in(0,1)$. In addition, define $\mathrm{k}_{\mathrm{SC} 2}$ such that $\mathrm{x}_{\mathrm{i}}\left(\mathrm{k}_{\mathrm{SC} 2}\right)=\mathrm{x}_{\mathrm{m}}$. Since $\mathrm{x}_{\mathrm{i}}\left(\mathrm{k}_{\mathrm{SC}}\right)$ is an increasing function of $\mathrm{k}_{\mathrm{SC}}$, max $\left\{\mathrm{x}_{\mathrm{m}}, \mathrm{x}_{\mathrm{i}}\left(\mathrm{k}_{\mathrm{SC}}\right)\right\}$ $=\mathrm{x}_{\mathrm{m}}$ for all $\mathrm{k}_{\mathrm{SC}} \in\left[0, \mathrm{k}_{\mathrm{SC} 2}\right]$ and $\max \left\{\mathrm{x}_{\mathrm{m}}, \mathrm{x}_{\mathrm{i}}\left(\mathrm{k}_{\mathrm{SC}}\right)\right\}=\mathrm{x}_{\mathrm{i}}\left(\mathrm{k}_{\mathrm{SC}}\right)$ for $\mathrm{k}_{\mathrm{SC}} \in\left[\mathrm{k}_{\mathrm{SC} 2}, \mathrm{k}_{\mathrm{SC} 3}\right]$.

We augment the notation for the function $\mathrm{V}_{\mathrm{i}}\left(\mathrm{p}_{\mathrm{M}},[0, \mathrm{x})\right)$ to reflect its dependence on $\mathrm{k}_{\mathrm{SC}}$ : $\mathrm{V}_{\mathrm{i}}\left(\mathrm{p}_{\mathrm{M}},[0, \mathrm{x}) ; \mathrm{k}_{\mathrm{SC}}\right)$. For $\mathrm{k}_{\mathrm{SC}} \in\left[0, \mathrm{k}_{\mathrm{SC} 2}\right]$, the expression of interest is $\mathrm{V}_{\mathrm{i}}\left(\mathrm{p}_{\mathrm{M}},\left[0, \mathrm{x}_{\mathrm{m}}\right) ; \mathrm{k}_{\mathrm{SC}}\right)$; on the other hand, for $\mathrm{k}_{\mathrm{SC}} \in\left[\mathrm{k}_{\mathrm{SC} 2}, \mathrm{k}_{\mathrm{SC} 3}\right]$, the expression of interest is $\mathrm{V}_{\mathrm{i}}\left(\mathrm{p}_{\mathrm{M}},\left[0, \mathrm{x}_{\mathrm{i}}\left(\mathrm{k}_{\mathrm{SC}}\right)\right) ; \mathrm{k}_{\mathrm{SC}}\right)$. It can be shown that: 1) $\mathrm{V}_{\mathrm{i}}\left(\mathrm{p}_{\mathrm{M}},\left[0, \mathrm{x}_{\mathrm{m}}\right) ; 0\right)>0 ;$ and 2) $\mathrm{V}_{\mathrm{i}}\left(\mathrm{p}_{\mathrm{M}},\left[0, \mathrm{x}_{\mathrm{m}}\right) ; \mathrm{k}_{\mathrm{SC} 2}\right)<0$ (see Appendix A for details). Since the function $\mathrm{V}_{\mathrm{i}}\left(\mathrm{p}_{\mathrm{M}},\left[0, \mathrm{x}_{\mathrm{m}}\right) ; \mathrm{k}_{\mathrm{SC}}\right)$ is continuous and strictly decreasing in $\mathrm{k}_{\mathrm{SC}}$, there exists a unique value $\mathrm{k}_{\mathrm{SC} 1} \in\left(0, \mathrm{k}_{\mathrm{SC} 2}\right)$ such that $\mathrm{V}_{\mathrm{i}}\left(\mathrm{p}_{\mathrm{M}},\left[0, \mathrm{x}_{\mathrm{m}}\right) ; \mathrm{k}_{\mathrm{SC} 1}\right)=0$; moreover, $\mathrm{x}_{\mathrm{m}}>\mathrm{x}_{\mathrm{i}}\left(\mathrm{k}_{\mathrm{SC} 1}\right)$. Finally, it can be shown that: 3) $\mathrm{V}_{\mathrm{i}}\left(\mathrm{p}_{\mathrm{M}},\left[0, \mathrm{x}_{\mathrm{i}}\left(\mathrm{k}_{\mathrm{SC}}\right)\right) ; \mathrm{k}_{\mathrm{SC}}\right)<0$ (again, see Appendix A for details).

Thus, we have established the following. For $\mathrm{k}_{\mathrm{SC}} \in\left[0, \mathrm{k}_{\mathrm{SC} 1}\right)$, only a Type I equilibrium exists: judge $\mathrm{m}$ never writes a dissent because, even absent a dissent, justice $\mathrm{i}$ will vote for cert based on her beliefs about $\mathrm{p}_{\mathrm{m}}$. However, as $\mathrm{k}_{\mathrm{SC}}$ rises, the function $\mathrm{V}_{\mathrm{i}}\left(\mathrm{p}_{\mathrm{M}},\left[0, \mathrm{x}_{\mathrm{m}}\right) ; \mathrm{k}_{\mathrm{SC}}\right)$ shifts down vertically and eventually the regime will transit to one wherein $x_{m}$ still exceeds $x_{i}$, but now $V_{i}\left(p_{M}\right.$, $\left.\left[0, \mathrm{x}_{\mathrm{m}}\right) ; \mathrm{k}_{\mathrm{SC}}\right) \leq 0$; this transition occurs at the value $\mathrm{k}_{\mathrm{SC} 1}$. For $\mathrm{k}_{\mathrm{SC}} \geq \mathrm{k}_{\mathrm{SC} 1}$, it is optimal for justice i not to vote for cert unless a dissenting opinion (revealing a sufficiently high value of $\mathrm{p}_{\mathrm{m}}$ ) is provided. Thus, judge $\mathrm{m}$ now writes a dissent for $\mathrm{p}_{\mathrm{m}} \in\left[\mathrm{x}_{\mathrm{m}}, 1\right]$ and justice $\mathrm{i}$ votes to grant cert if and only if a 
dissenting opinion reporting $\mathrm{p}_{\mathrm{m}} \in\left[\mathrm{x}_{\mathrm{m}}, 1\right]$ is received; now a Type IIa equilibrium exists. ${ }^{28}$ As $\mathrm{k}_{\mathrm{SC}}$ rises still further, $\mathrm{x}_{\mathrm{i}}\left(\mathrm{k}_{\mathrm{SC}}\right)$ rises until it reaches $\mathrm{x}_{\mathrm{m}}$ (this transition occurs at the value $\mathrm{k}_{\mathrm{SC} 2}$ ). Finally, for $\mathrm{k}_{\mathrm{SC}} \in\left(\mathrm{k}_{\mathrm{SC} 2}, \mathrm{k}_{\mathrm{SC} 3}\right]$, a Type IIa equilibrium continues to exist, but now judge $\mathrm{m}$ writes a dissent for $\mathrm{p}_{\mathrm{m}} \in\left[\mathrm{x}_{\mathrm{i}}\left(\mathrm{k}_{\mathrm{SC}}\right), 1\right]$ and justice $\mathrm{i}$ votes to grant cert if and only if a dissenting opinion reporting $\mathrm{p}_{\mathrm{m}} \in$ $\left[\mathrm{x}_{\mathrm{i}}\left(\mathrm{k}_{\mathrm{SC}}\right), 1\right]$ is received; this set becomes progressively smaller as $\mathrm{k}_{\mathrm{SC}}$ rises, until finally the set becomes empty at $\mathrm{k}_{\mathrm{SC} 3}$.

Collecting the implications of these arguments for the writing of dissents and for cert votes yields Figure 3 below (where $\mathrm{x}_{\mathrm{i}}\left(\mathrm{k}_{\mathrm{SC}}\right)$ is, for simplicity, illustrated as a line). Notice that the transition

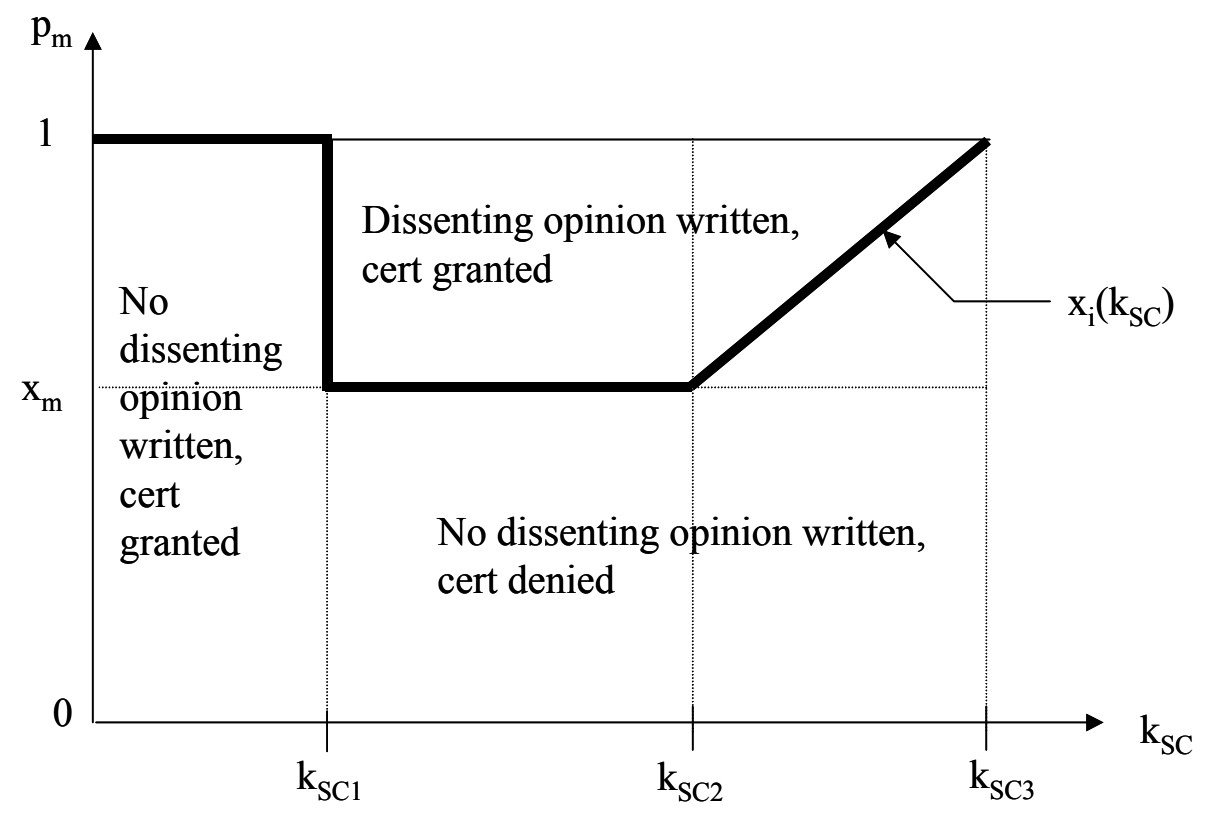

Figure 3: Equilibrium Outcomes as a Function of $\mathrm{k}_{\mathrm{SC}}$

28 The two types of equilibrium co-exist for some values of $\mathrm{k}_{\mathrm{SC}}>\mathrm{k}_{\mathrm{SC} 1}$, but the Type I equilibrium cannot exist for $\mathrm{k}_{\mathrm{SC}}$ in a neighborhood of $\mathrm{k}_{\mathrm{SC} 3}$ (it is possible that the Type I equilibrium fails to exist for $\mathrm{k}_{\mathrm{SC}}<\mathrm{k}_{\mathrm{SC} 2}$ ). In the following figure, when (for a given value of $\mathrm{k}_{\mathrm{SC}}$ ) multiple equilibria exist, we select the more informative (Type IIa) equilibrium. 
occurring at $\mathrm{k}_{\mathrm{SC} 1}$ is quite dramatic. For costs slightly lower than $\mathrm{k}_{\mathrm{SC} 1}$, judge $\mathrm{m}$ does not write any dissents (and the supreme court grants cert for all cases), while for costs slightly higher than $\mathrm{k}_{\mathrm{SC} 1}$ judge $\mathrm{m}$ provides a dissent for all $\mathrm{p}_{\mathrm{m}} \in\left[\mathrm{x}_{\mathrm{m}}, 1\right]$. If we interpret $\mathrm{k}_{\mathrm{SC}}$ as a policy lever for the supreme court (that is, it can "set" $\mathrm{k}_{\mathrm{SC}}$ higher than its actual value), then the supreme court can employ restricted access to induce information revelation and effective screening on the part of judge $\mathrm{m}$. Writing Equilibrium with Unsympathetic and Persuadable Justices: Strange Bedfellows Now assume that the court is composed of one unsympathetic and persuadable justice i, and two justices who are predisposed to deny cert. A candidate for a pure-strategy writing equilibrium (a Type IIb equilibrium) involves the possibility that judge $\mathrm{m}$ will write an opinion for an interior interval of $p_{m}$ values. This is illustrated in Figure 4 below where $V_{i}$ is downward sloping with critical value $x_{i}$ while $V_{m}$ and $x_{m}$ are the same as before. Again, we need to consider two cases: $x_{m}$

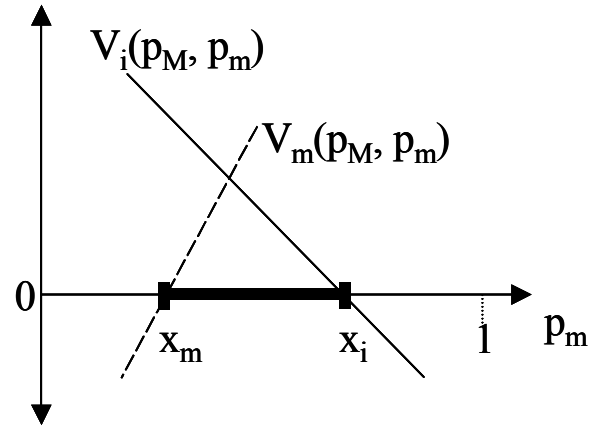

(a) $x_{m} \leq x_{i}$

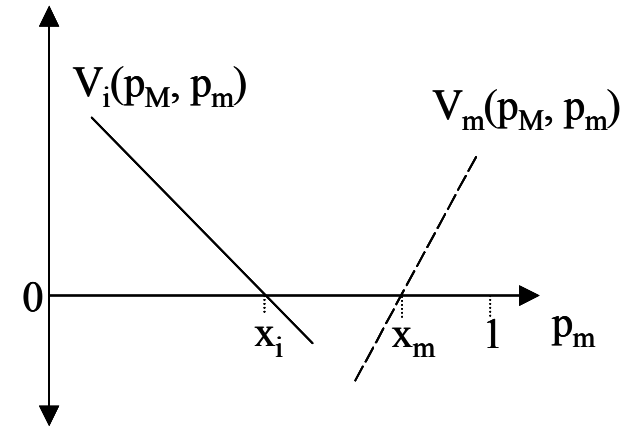

(b) $x_{m}>x_{i}$

Figure 4: $\mathrm{V}_{\mathrm{i}}, \mathrm{V}_{\mathrm{m}}$ and Type IIb Equilibria

$\leq x_{i}$, which is illustrated in Figure 4(a) and $x_{m}>x_{i}$, which is illustrated in Figure 4(b). The set of $p_{m}-$ values for which judge $\mathrm{m}$ writes an opinion is darkened for emphasis. 
If $x_{m} \leq x_{i}$, then there is an interval $\left[x_{m}, x_{i}\right]$ of values of $p_{m}$ for which judge $m$ would be willing to write a dissent in order to provoke cert, and for which justice $\mathrm{i}$ would be willing to vote to grant cert upon receiving a dissenting opinion revealing $\mathrm{p}_{\mathrm{m}} \in\left[\mathrm{x}_{\mathrm{m}}, \mathrm{x}_{\mathrm{i}}\right] .{ }^{29}$ This means that judge $\mathrm{m}$ and justice i are "strange bedfellows" in the sense that while their preferences are at least moderately opposed, there is mutual advantage to communication (via an opinion by judge $m$ ) in the overlapping, darkened interval indicated in Figure 4(a). Judge $m$ is willing to write because $p_{m}$ is not too low, while justice $i$ is willing to vote to grant cert because $p_{m}$ is not too high.

Notice that this type of equilibrium could not exist if the supreme court justices were motivated only by error correction. Pure error correction corresponds to $\mathrm{u}^{\mathrm{B}}=\mathrm{u}^{\mathrm{SB}}>\mathrm{u}^{\mathrm{W}}=\mathrm{u}^{\mathrm{SW}}$, which implies that $\gamma_{i}^{R}=0$ and $V_{i}\left(p_{M}, p_{m}\right)=\rho\left(p_{M}, p_{m}\right)\left(2 \alpha_{i}^{P}-1\right)-k_{S C}$. Now if justice $i$ is unsympathetic, $\alpha_{i}^{P}$ $<1 / 2$, so $\mathrm{V}_{\mathrm{i}}\left(\mathrm{p}_{\mathrm{M}}, \mathrm{p}_{\mathrm{m}}\right)<0$ for all $\mathrm{p}_{\mathrm{m}}$ and hence justice $\mathrm{i}$ is predisposed to deny cert. Thus, the "strange bedfellows" equilibrium arises only if justice i actually expects to approve of the appeals court's decision (with sufficiently high probability) and wants to grant cert for the purpose of broadening the precedent. To see this, note that a necessary condition for an unsympathetic justice to be persuadable is $\gamma_{i}^{\mathrm{R}}=\alpha_{\mathrm{i}}^{\mathrm{R}}\left(\mathrm{u}^{\mathrm{B}}-\mathrm{u}^{\mathrm{SB}}\right)+\left(1-\alpha_{\mathrm{i}}^{\mathrm{R}}\right)\left(\mathrm{u}^{\mathrm{W}}-\mathrm{u}^{\mathrm{SW}}\right)>0$, which implies that $\alpha_{i}^{\mathrm{R}}$ and $\mathrm{u}^{\mathrm{B}}-\mathrm{u}^{\mathrm{SB}}$ must be sufficiently greater than zero.

If, however, $x_{m}>x_{i}\left(\right.$ as in Figure 4(b)), then judge $m$ would not write a dissent for any $p_{m} \in$ $[0,1]$; he would not write for $\mathrm{p}_{\mathrm{m}} \in\left[0, \mathrm{x}_{\mathrm{m}}\right)$ even if doing so would provoke cert, since writing is costly, and he would not write for $\mathrm{p}_{\mathrm{m}} \in\left[\mathrm{x}_{\mathrm{m}}, 1\right]$ because justice $\mathrm{i}$ would respond by voting to deny cert. Here we do not have strange bedfellows, because the degree of opposition of interests has

29 As before, the assignment of the endpoints of the interval (to the writing versus nonwriting set) is arbitrary: there is another writing equilibrium in which $\mathrm{p}_{\mathrm{m}} \in\left(\mathrm{x}_{\mathrm{m}}, \mathrm{x}_{\mathrm{i}}\right)$. Again, we ignore this inessential multiplicity, which also arises in Type IIc equilibria below. 
eliminated the possibility of equilibrium communication.

Thus, a Type IIb pure-strategy equilibrium involves judge $m$ writing a dissenting opinion if and only if $\mathrm{p}_{\mathrm{m}} \in\left[\mathrm{x}_{\mathrm{m}}, \mathrm{x}_{\mathrm{i}}\right]$. Moreover, judge $\mathrm{m}$ would write only if it is necessary to provoke cert; that is, only if cert would be denied absent a dissenting opinion. This type of equilibrium can exist if and only if it is optimal for justice $\mathrm{i}$ to vote to deny cert upon receiving no opinion when judge $\mathrm{m}$ writes only for $\mathrm{p}_{\mathrm{m}} \in\left[\mathrm{x}_{\mathrm{m}}, \mathrm{x}_{\mathrm{i}}\right]$; that is, if and only if $\mathrm{V}_{\mathrm{i}}\left(\mathrm{p}_{\mathrm{M}},\left[0, \mathrm{x}_{\mathrm{m}}\right) \cup\left(\mathrm{x}_{\mathrm{i}}, 1\right]\right)=\mathrm{E}\left\{\mathrm{V}_{\mathrm{i}}\left(\mathrm{p}_{\mathrm{M}}, \mathrm{p}_{\mathrm{m}}\right) \mid \mathrm{p}_{\mathrm{m}} \in\left[0, \mathrm{x}_{\mathrm{m}}\right) \cup\right.$ $\left.\left(\mathrm{x}_{\mathrm{i}}, 1\right]\right\} \leq 0$. When $\mathrm{x}_{\mathrm{m}}>\mathrm{x}_{\mathrm{i}}$, the interval $\left[\mathrm{x}_{\mathrm{m}}, \mathrm{x}_{\mathrm{i}}\right]$ is empty and $\mathrm{V}_{\mathrm{i}}\left(\mathrm{p}_{\mathrm{M}},\left[0, \mathrm{x}_{\mathrm{m}}\right) \cup\left(\mathrm{x}_{\mathrm{i}}, 1\right]\right)=\mathrm{V}_{\mathrm{i}}\left(\mathrm{p}_{\mathrm{M}},[0,1]\right)$. If $\mathrm{V}_{\mathrm{i}}\left(\mathrm{p}_{\mathrm{M}},[0,1]\right) \leq 0$, then there is a degenerate version of a Type IIb equilibrium, wherein judge $\mathrm{m}$ never writes a dissenting opinion and justice i votes to deny cert without a dissenting opinion.

The arguments above generalize straightforwardly to the case of one to three unsympathetic and persuadable justices (indexed by i), again assuming that any remaining justices are predisposed to deny cert. Let $\mathrm{x}^{\mathrm{U}} \equiv \max _{\mathrm{i}}\left\{\mathrm{x}_{\mathrm{i}}\right\}$ and define a Type IIb equilibrium as follows.

Definition 5. Type IIb Equilibrium: Judge $\mathrm{m}$ writes a dissenting opinion if and only if $\mathrm{p}_{\mathrm{m}}$ $\in\left[\mathrm{x}_{\mathrm{m}}, \mathrm{x}^{\mathrm{U}}\right]$; at least one justice votes to grant cert upon receipt of such an opinion. All justices vote to deny cert without a dissenting opinion.

In Proposition 3 below, we summarize the conditions under which each type of equilibrium exists for the case of one unsympathetic and persuadable justice (the proof is in Appendix A). In the general case with more than one unsympathetic and persuadable justice, existence in pure strategies is not guaranteed; this case is discussed in Appendix A (where the corresponding proposition is labeled Proposition 3').

Proposition 3. There are only two possible types of pure-strategy equilibrium for the case of one unsympathetic and persuadable justice, assuming that the remaining justices are 
predisposed to deny cert; at least one pure-strategy equilibrium exists.

(a) If $\mathrm{E}\left\{\mathrm{V}_{\mathrm{i}}\left(\mathrm{p}_{\mathrm{M}}, \mathrm{p}_{\mathrm{m}}\right) \mid \mathrm{p}_{\mathrm{m}} \in\left[0, \mathrm{x}_{\mathrm{m}}\right) \cup\left(\mathrm{x}_{\mathrm{i}}, 1\right]\right\}>0$, then only a Type I equilibrium exists.

(b) If $\mathrm{E}\left\{\mathrm{V}_{\mathrm{i}}\left(\mathrm{p}_{\mathrm{M}}, \mathrm{p}_{\mathrm{m}}\right) \mid \mathrm{p}_{\mathrm{m}} \in[0,1]\right\}<0$, then only a Type IIb equilibrium exists.

(c) If $\mathrm{E}\left\{\mathrm{V}_{\mathrm{i}}\left(\mathrm{p}_{\mathrm{M}}, \mathrm{p}_{\mathrm{m}}\right) \mid \mathrm{p}_{\mathrm{m}} \in\left[0, \mathrm{x}_{\mathrm{m}}\right) \cup\left(\mathrm{x}_{\mathrm{i}}, 1\right]\right\} \leq 0$ and $\mathrm{E}\left\{\mathrm{V}_{\mathrm{i}}\left(\mathrm{p}_{\mathrm{M}}, \mathrm{p}_{\mathrm{m}}\right) \mid \mathrm{p}_{\mathrm{m}} \in[0,1]\right\} \geq 0$, then both a Type I and a Type IIb equilibrium exist.

It is clear (from the proof of Proposition 2 in Appendix B) that the comparative static effects of the parameters $\mathrm{u}^{\mathrm{B}}, \mathrm{u}^{\mathrm{SB}}, \mathrm{u}^{\mathrm{SW}}, \mathrm{u}^{\mathrm{W}}, \mathrm{k}_{\mathrm{SC}}, \alpha_{\mathrm{i}}^{\mathrm{P}}$ and $\alpha_{\mathrm{i}}^{\mathrm{R}}$ on the critical value $\mathrm{x}_{\mathrm{i}}$ all now have the opposite sign from the case of sympathetic justices, while the sign of the comparative static effect of the majority opinion $\mathrm{p}_{\mathrm{M}}$ on $\mathrm{x}_{\mathrm{i}}$ remains the same, and $\mathrm{x}_{\mathrm{i}}$ is still independent of $\mathrm{k}_{\mathrm{AC}}$. However, because an unsympathetic justice $\mathrm{i}$ votes to grant cert for $\mathrm{p}_{\mathrm{m}} \in\left[0, \mathrm{x}_{\mathrm{i}}\right]$, it remains true that justice $\mathrm{i}$ would be willing to vote to grant cert for a larger set $\left[0, x_{i}\right]$ of realizations of $\mathrm{p}_{\mathrm{m}}$ if $\mathrm{u}^{\mathrm{B}}, \mathrm{u}^{\mathrm{W}}, \alpha_{\mathrm{i}}^{\mathrm{P}}$ or $\alpha_{i}^{\mathrm{R}}$ were higher or if $\mathrm{u}^{\mathrm{SB}}, \mathrm{u}^{\mathrm{SW}}$, or $\mathrm{k}_{\mathrm{SC}}$ were lower (and for the same reasons). For an unsympathetic justice, an increase in $p_{M}$ reduces the net value to justice $i$ of voting to grant cert, which reduces the set of $p_{m}$ values $\left[0, \mathrm{x}_{\mathrm{i}}\right]$ for which she will vote to grant cert.

Writing Equilibrium with Conflicting Sympathies

Finally, we consider the case of conflicting sympathies on the part of the justices. First, suppose that one justice $\mathrm{i}$ is sympathetic and persuadable, while another justice $\mathrm{j}$ is unsympathetic and persuadable, and assume for the moment that the third justice is predisposed to deny cert. Then $\mathrm{V}_{\mathrm{i}}\left(\mathrm{p}_{\mathrm{M}}, \mathrm{p}_{\mathrm{m}}\right)$ is increasing in $\mathrm{p}_{\mathrm{m}}$ with critical value $\mathrm{x}_{\mathrm{i}}$ and $\mathrm{V}_{\mathrm{j}}\left(\mathrm{p}_{\mathrm{M}}, \mathrm{p}_{\mathrm{m}}\right)$ is decreasing in $\mathrm{p}_{\mathrm{m}}$ with critical value $\mathrm{x}_{\mathrm{j}}$. The form of a candidate for a pure strategy writing equilibrium (Type IIc) can be obtained through the following argument. Judge $m$ will never write a dissenting opinion for $\mathrm{p}_{\mathrm{m}} \in\left[0, \mathrm{x}_{\mathrm{m}}\right)$, even if doing so would provoke cert. However, judge $\mathrm{m}$ will be able to persuade the unsympathetic 
justice $\mathrm{j}$ to vote to grant cert by writing a dissenting opinion for $\mathrm{p}_{\mathrm{m}} \in\left[\mathrm{x}_{\mathrm{m}}, \mathrm{x}_{\mathrm{j}}\right]$, where we take the interval $\left[x_{m}, x_{j}\right]$ to be empty if $x_{m}>x_{j}$. In addition, judge $m$ will be able to persuade the sympathetic justice $\mathrm{i}$ to vote to grant cert by writing a dissenting opinion for $\mathrm{p}_{\mathrm{m}} \in\left[\mathrm{x}_{\mathrm{i}}, 1\right]$. Combining these three observations implies that the region in which judge $m$ will find it optimal to write an opinion in order to provoke cert is given by $\mathrm{p}_{\mathrm{m}} \in\left[\mathrm{x}_{\mathrm{m}}, \mathrm{x}_{\mathrm{j}}\right] \cup\left[\max \left\{\mathrm{x}_{\mathrm{m}}, \mathrm{x}_{\mathrm{i}}\right\}, 1\right]$.

The case of one sympathetic and persuadable justice $\mathrm{i}$ and one unsympathetic and persuadable justice $\mathrm{j}$ is depicted in Figure 5 below for $\mathrm{x}_{\mathrm{i}}>\mathrm{x}_{\mathrm{j}}$ (the case of $\mathrm{x}_{\mathrm{i}} \leq \mathrm{x}_{\mathrm{j}}$ is discussed following Proposition 4). There are multiple possible locations for $\mathrm{x}_{\mathrm{m}}$ relative to $\mathrm{x}_{\mathrm{i}}$ and $\mathrm{x}_{\mathrm{j}}$, but the

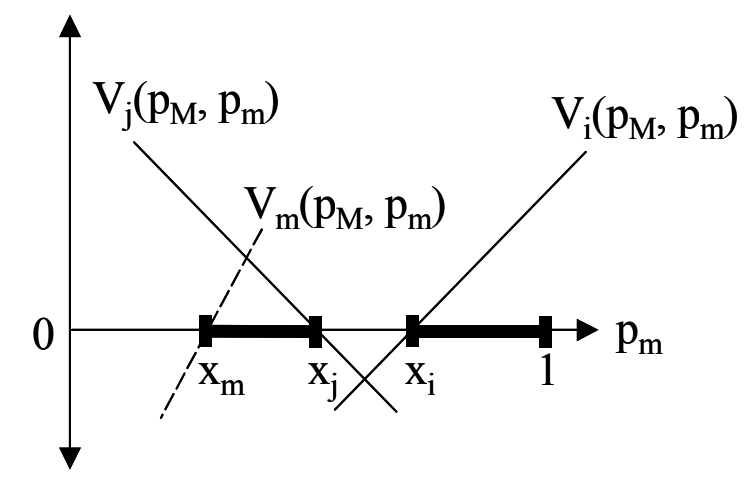

\section{Figure 5: $\mathrm{V}_{\mathrm{i}}, \mathrm{V}_{\mathrm{j}}, \mathrm{V}_{\mathrm{m}}$ and Type IIc Equilibria}

analysis is straightforward for all possible locations of $x_{m}$; Figure 5 illustrates the case of $x_{m}<x_{j}$. The values of $\mathrm{p}_{\mathrm{m}}$ for which judge $\mathrm{m}$ writes an opinion in equilibrium are darkened for emphasis.

Note that, once again, there are "strange bedfellows" in this equilibrium; the intensity of opposition of justice $\mathrm{i}$ and justice $\mathrm{j}$ has led to a "hole" in the usually-connected interval representing the values of $p_{m}$ for which judge $m$ would write. Thus, in this example, judge $m$ is writing either to persuade justice i or justice $\mathrm{j}$, but not both. 
The foregoing arguments can be generalized to the remaining cases of (i) one sympathetic justice and two unsympathetic justices; and (ii) two sympathetic justices and one unsympathetic justice. Let $\mathrm{x}^{\mathrm{S}}=\min _{\mathrm{i}}\left\{\mathrm{x}_{\mathrm{i}}\right\}$, where $\mathrm{i}$ denotes a sympathetic and persuadable justice, and let $\mathrm{x}^{\mathrm{U}}=$ $\max _{\mathrm{j}}\left\{\mathrm{x}_{\mathrm{j}}\right\}$, where $\mathrm{j}$ denotes an unsympathetic and persuadable justice.

Definition 6. Type IIc Equilibrium: Judge $\mathrm{m}$ writes a dissenting opinion if and only if $\mathrm{p}_{\mathrm{m}}$ $\in\left[\mathrm{x}_{\mathrm{m}}, \mathrm{x}^{\mathrm{U}}\right] \cup\left[\max \left\{\mathrm{x}_{\mathrm{m}}, \mathrm{x}^{\mathrm{S}}\right\}, 1\right]$; at least one justice votes to grant cert upon receipt of such an opinion. All justices vote to deny cert without a dissenting opinion.

The following proposition summarizes conditions under which each type of equilibrium can exist; the proof is in Appendix B.

Proposition 4 . There are only two possible types of pure-strategy equilibrium for a collection of persuadable justices, some of whom are sympathetic, some of whom are unsympathetic and (at most) one of whom is predisposed to deny cert.

(a) If $\max _{\mathrm{k}}\left\{\mathrm{E}\left\{\mathrm{V}_{\mathrm{k}}\left(\mathrm{p}_{\mathrm{M}}, \mathrm{p}_{\mathrm{m}}\right) \mid \mathrm{p}_{\mathrm{m}} \in\left[0, \mathrm{x}_{\mathrm{m}}\right) \cup\left(\mathrm{x}^{\mathrm{U}}, \mathrm{x}^{\mathrm{S}}\right)\right\}\right\} \leq 0$, then a Type IIc equilibrium exists.

(b) If $\max _{\mathrm{k}}\left\{\mathrm{E}\left\{\mathrm{V}_{\mathrm{k}}\left(\mathrm{p}_{\mathrm{M}}, \mathrm{p}_{\mathrm{m}}\right) \mid \mathrm{p}_{\mathrm{m}} \in[0,1]\right\}\right\} \geq 0$, then a Type I equilibrium exists.

Both hypotheses above could hold simultaneously, supporting both types of equilibrium. However, we cannot rule out the possibility that neither of these hypotheses holds, in which case there is no pure-strategy equilibrium; the nature of the mixing needed to support a mixed-strategy equilibrium is that one or more justices must randomize after receiving no dissenting opinion. For example, the need for randomization may arise when $\mathrm{x}_{\mathrm{m}}<\mathrm{x}_{\mathrm{i}}<\mathrm{x}_{\mathrm{j}}$ and there is one sympathetic and persuadable justice and one unsympathetic and persuadable justice. The candidate equilibrium writing set $\left[\mathrm{x}_{\mathrm{m}}, \mathrm{x}_{\mathrm{j}}\right] \cup\left[\max \left\{\mathrm{x}_{\mathrm{m}}, \mathrm{x}_{\mathrm{i}}\right\}, 1\right]$ reduces to $\left[\mathrm{x}_{\mathrm{m}}, 1\right]$, and thus the non-writing set is simply 
$\left[0, x_{m}\right)$. However, since $V^{j}\left(p_{M}, p_{m}\right)>0$ for all $p_{m} \in\left[0, x_{m}\right)$, it follows that $E\left\{V_{j}\left(p_{M}, p_{m}\right) \mid p_{m} \in\left[0, x_{m}\right)\right\}$ $>0$, and thus the unsympathetic justice will vote for cert upon receiving no dissent (upsetting a Type IIc equilibrium). If conditions were such that the Type I equilibrium also did not exist, one could construct a mixed-strategy writing equilibrium, wherein at least one justice would randomize over voting to grant or deny cert when judge $m$ does not write, and judge $m$ would write for a smaller domain of $\mathrm{p}_{\mathrm{m}}$ values than $\left[\mathrm{x}_{\mathrm{m}}, 1\right]$.

\section{$\underline{\text { Uncertainty and Failure to Garner Cert }}$}

The common observable characteristic of the family of Type II equilibria discussed above is that when judge $\mathrm{m}$ writes a dissent, the supreme court grants cert. We don't observe such regularity in reality; dissents are written but cert is denied. A simple extension of our analysis indicates one possible reason: $\mathrm{k}_{\mathrm{SC}}$ is not common knowledge for $\mathrm{AC}$ and $\mathrm{SC}$. The simplest extension is for $\mathrm{k}_{\mathrm{SC}}$ to be a random variable from AC's perspective, with a distribution that is common knowledge to $\mathrm{AC}$ and $\mathrm{SC}$ (the actual value of $\mathrm{k}_{\mathrm{SC}}$ can still be viewed as common knowledge within SC). For example, as discussed earlier, $\mathrm{k}_{\mathrm{SC}}$ reflects both the direct effort of a justice who hears and decides a case plus the opportunity costs for a justice of considering other cases which might also serve her purposes of influencing law. It is this latter opportunity cost that is unlikely to be known by an $\mathrm{AC}$ judge when considering whether to write an opinion, but may be very clear to the justices on SC when the cert petitions actually arrive. Thus, in the simplest extension of the analysis, where judge $\mathrm{m}$ employs a distribution over $\mathrm{k}_{\mathrm{SC}}$, this will lead to judge $\mathrm{m}$ sometimes writing opinions that fail to achieve the necessary (realized) value for $\mathrm{V}_{\mathrm{i}}$. 


\section{Summary, Implications and Potential Extensions}

\section{$\underline{\text { Summary and Implications }}$}

In the model presented above we integrate information, ideology/jurisprudence and strategy to analyze the incentives for a dissenting judge on an appeals court to communicate privatelyobserved attributes of a case to justices of a supreme court. The dissenter's intent is to promote a review of the case so that the majority position on the appeals court will be reversed and a systemwide precedent will be established. By the same token, this means that the supreme court can use restricted access to capitalize on the desire of appeals courts judges to influence the evolution of the law, so as to help screen cases for review. We focus on a dissenting judge and a given case, but as outlined in the Introduction, dissent by judges on an appeals court can come in other forms.

In the analysis we characterize sympathetic (unsympathetic) justices, where this refers to the degree of positive (negative) correlation of a justice's willingness to vote to grant cert and the minority judge's preferences on cert. Ideological closeness is also likely to be stronger (weaker) between a sympathetic (unsympathetic) justice and the dissenter. If all justices are predisposed on the issue of cert, there is no need for communication, so we analyze the cases wherein no justices are predisposed in favor of cert, but some justices (perhaps all) are persuadable. A persuadable justice's optimal choice to vote to grant or deny cert depends upon the minority judge's information, which is either revealed or inferred.

We characterize two general classes of equilibria. The first class (Type I) involves no opinion being written by the dissenter and cert being granted; this equilibrium will disappear if the judicial cost for supreme court justices $\left(\mathrm{k}_{\mathrm{SC}}\right)$ is high enough. The second class (including Types IIa, IIb and IIc) varies in detail from scenario to scenario, but involves cert being granted if and only if 
judge $m$ writes an opinion. The space of possible reports (written opinions) is the interval $[0,1]$, the domain for the privately-observed signal. If the supreme court is comprised of sympathetic justices, then the equilibrium sub-interval for writing an opinion (this is a Type IIa equilibrium) is of the form $[\mathrm{x}, 1]$, where $\mathrm{x}$ depends upon the characteristics of the dissenting judge and the sympathetic and persuadable justice(s). Thus, if a judge's private information about the supreme court's likelihood of reversal is high enough (above $\mathrm{x}$ ), he will write an opinion and cert will be granted. Moreover, no opinion (or one revealing a low signal) will result in the denial of cert.

While Judge Posner's majority opinion in the Khan v. State Oil case is not, technically, in the domain of our model (the source of dissent here was the majority opinion), this example would seem to fit under a fairly direct extension of our model. Precedent (as articulated in Albrecht) constrained the Appeals Court to vote a particular way, but privately-observed information (bringing new arguments to the discussion) strongly supported the loser in the case and impugned the policy embodied in Albrecht. The Appeals Court's opinion revealed a very high probability that the existing Supreme Court would want to reverse this case and change the law system-wide (change from maximum-resale-price-maintenance contracting being a per se Sherman Act violation to employing a rule-of-reason criterion for evaluating possible antitrust cases similar to Khan).

When the supreme court's persuadable justices are unsympathetic, the equilibrium subinterval for writing an opinion is interior to $[0,1]$ (this was a Type IIb equilibrium). This case presents the interesting feature which we refer to as "strange bedfellows." When at least one justice is unsympathetic and all remaining justices are predisposed against cert, this means that if the dissenting judge's private information is in the equilibrium interval for writing opinions, then he is purposely communicating with a justice whose ideological leanings are likely to be quite different 
from his, and that justice is voting for cert thereby furthering the interests of a judge with whom she may (ultimately) disagree about the policy issue in question. They both find mutual advantage in this equilibrium. This is not because of errors (e.g., excessive optimism) on one or both of their parts; rather, it reflects the differences in payoffs each receives. Intuitively, the equilibrium "writing interval" involves posterior probabilities that the supreme court will reverse the appeals court which are not so high as to make the unsympathetic justice wish to deny cert, but not so low as to make the dissenting judge choose the option of no opinion.

An example of this is Judge Alex Kozinski's 1986 dissent in International Olympic Committee v. San Francisco Arts \& Athletics. A panel of the Ninth Circuit (which did not include Judge Kozinski) affirmed an injunction preventing SFAA from using the term "Gay Olympics," finding that Congress had (statutorily) granted the U.S. Olympic Committee control over the use of the term "Olympics." The Ninth Circuit subsequently denied a petition to re-hear the case en banc (that is, by a much larger panel of judges drawn from the Circuit), from which Judge Kozinski (and two colleagues) dissented, asserting (among other things) that the statute might conflict with the First Amendment and that the issues deserved the careful scrutiny of further review. This dissent revealed a "middling" value of $\mathrm{p}_{\mathrm{m}}{ }^{30}$ The Supreme Court granted cert, but affirmed the original Appeals Court decision by a 7-2 margin. Since at least four justices must vote for cert, this strongly suggests that some who voted for cert were unsympathetic.

30 "By raising these concerns I do not necessarily conclude that the Amateur Act is irreconcilably at odds with the first amendment. Indeed, on this barren record I find it difficult to reach any but the most tentative conclusions about this highly unusual statue and its affect upon our personal liberties.... With all due respect, the panel's offhand approval of this injunction, ..., simply does not measure up to the close appellate scrutiny due first amendment claims and defenses." IOC v. SFAA (1986) 789 F.2d 1319, pp. 1325-26. 
Finally, should there be a conflict of sympathies on the supreme court, one may get multiple, disconnected sub-intervals in which judge $m$ will write, as illustrated in Figure 5: for somewhat low signals the judge is writing to influence the unsympathetic justice, while for a higher set of signals the judge is writing to influence the sympathetic justice.

The supreme court's opportunity cost parameter, $\mathrm{k}_{\mathrm{SC}}$, plays a central role. We conceive of this exogenous parameter as reflecting the tightness of the cert budget: substantial decreases in the average number of petitions for certiorari that were granted (as occurred from the 1970's into the 1990 's) are presumed to imply increased levels of $\mathrm{k}_{\mathrm{SC}}{ }^{31}$ Increases in this cost eventually mean that only non-Type I equilibria (i.e., Types IIa, IIb or IIc) will exist. This means that promotion (by a judge) of the "right sort of case" (that is, receiving private information on a case that lies in the appropriate sub-interval, and then writing an opinion revealing it) becomes necessary for cert to be granted (assuming the presence of some persuadable justices): judges act as screeners of the cases most likely to be of interest to justices.

\section{$\underline{\text { Potential Extensions }}$}

We raise three potential extensions. First, the current model allows for one dissenting judge from one appeals court. In the analysis, $\mathrm{k}_{\mathrm{SC}}$ represents both direct effort (hearing, negotiating and deciding efforts) and the opportunity foregone of taking some other case via which a justice could pursue her perspective about how the law should evolve. One extension would be to allow for competing dissents, thereby endogenizing the opportunity-cost portion of $\mathrm{k}_{\mathrm{SC}}$. We speculate that

${ }^{31}$ An alternative explanation for the decline is a principal-agent problem associated with the operation of the "cert pool" (see footnote 11): clerks are risk averse and under-recommend cases for further consideration. Of course, from our perspective, justices anticipate this reaction and design the rules and rewards to induce this outcome. 
competition is likely to further refine (and reduce) the set of cases that judges promote to the court for consideration. Alternatively put, extending our analysis to allow multiple dissents would develop a notion of a "demand for cert," one that reflects the competition of possible vehicles for the justices to use to affect the law. Note that, since any potential dissenting AC judge would not be fully aware of the other cases that might lead to cert petitions, the opportunity-cost portion of $\mathrm{k}_{\mathrm{SC}}$ would be stochastic from that judge's perspective. Thus, for example, in equilibrium dissents would be written but cert might not be granted.

A second extension of the analysis in this paper would be to understand the "supply of cert" that comes from a supreme court, a supply that is organized quite differently than occurs in the economist's usual notion of supply. This difference arises because it takes joint action by a subset of justices (generally, at least four on the real Supreme Court) to allocate a space within the cert budget to a specific case; thus, property rights are effected by subsets of agents, not individual agents. In addition, there seems to be the longer-run budget-sizing question. Given the great volume of cases, it seems reasonable that some decision process has been employed to control how the resource (hearing and decision-making at the supreme court) is to be allocated. We have referred to this as the "cert budget," which may be a somewhat soft constraint, but seems to be increasingly subject to guidance and control, since earlier decades involved substantially more cases being granted cert. Thus, this extension involves modeling how a supreme court chooses its cert budget and the rules by which subsets of justices can allocate it.

Finally, this paper has examined how a particular "weak hierarchy" (wherein a higher court needs information from a lower court, but can neither directly reward nor discipline lower-level judges) creates incentives for information revelation. Other such organizational structures come to 
mind (e.g., a faculty committee reporting to a faculty, or a committee reporting to a legislative body, might have dissenting members), though our model will require some modification to faithfully represent these settings; these remain topics for future research. 


\section{REFERENCES}

Caldeira, Gregroy A., John R. Wright and Christopher J.W. Zorn. "Strategic Voting and Gatekeeping in the Supreme Court," Journal of Law, Economics, and Organization, 1999, $\underline{15}(3)$, pp. 549-72.

Cameron, Charles M., Jeffrey A. Segal and Donald Songer. "Strategic Auditing in a Political Hierarchy: An Informational Model of the Supreme Court's Certiorari Decisions," American Political Science Review, 2000, 94(1), pp. 101-16.

Cooter, Robert and Thomas Ulen. Law and Economics, $3^{\text {rd }}$ Ed. Reading, MA.: Addison Wesley Longman, Inc., 2000.

Cross, Frank B. and Emerson H. Tiller. "Judicial Partisanship and Obedience to Legal Doctrine: Whistleblowing on the Federal Courts of Appeals," Yale Law Journal, 1998, 107, pp. 2155 76.

Daughety, Andrew F. and Jennifer F. Reinganum. "Stampede to Judgment: Persuasive Influence and Herding behavior by Courts," American Law and Economic Review, 1999, 1(1-2), pp.158-89.

Daughety, Andrew F. and Jennifer F. Reinganum. "Appealing Judgments," The Rand Journal of Economics, 2000, 31(3), pp. 502-25.

Elias, Paul. "Nine Opinions - But Still in Jail," The Recorder/Cal Law, January 27, 2000.

Edelman, Paul H. and Suzanna Sherry. "All or Nothing: Explaining the Size of Supreme Court Majorities," North Carolina Law Review, 2000, 78 (5), pp. 1225-52.

Epstein, Lee and Jack Knight. The Choices Justices Make. Washington, D.C.: Congressional Quarterly, 1998.

Epstein, Lee, Jeffrey A. Segal, Harold J. Spaeth and Thomas G. Walker. The Supreme Court Compendium, $2^{\text {nd }} E d$. Washington: Congressional Quarterly, Inc., 1996.

Milgrom, Paul R. and Robert J. Weber. "A Theory of Auctions and Competitive Bidding," Econometrica, September 1982, 50 (5), pp. 1089-1122.

Perry, H.W. Deciding to Decide. Cambridge, MA: Harvard University Press, 1991.

Posner, Richard A. "What Do Judges and Justices Maximize? (The Same Thing Everybody Else Does)," Supreme Court Economic Review, 1993, 3, pp. 1-42.

Shavell, Steven. "The Appeals Process as a Means of Error Correction," Journal of Legal 
Studies, 1995, 24 (2), pp. 379-426.

Schwartz, Edward P. "Policy, Precedent, and Power: A Positive Theory of Supreme Court Decision-Making," Journal of Law, Economics, and Organization, 1992, $\underline{8}(2)$, pp. 219-52.

Spitzer, Matt and Eric Talley. "Judicial Auditing," The Journal of Legal Studies, 2000, XXIV(2,Pt.1), pp. 649-84.

Tanenhaus, Joseph, Marvin Schick, Matthew Muraskin and Daniel Rosen. The Supreme COurt's Certiorari Jurisdiction: Cue Theory," in Judicial Decision Making, ed. Glendon Schubert. Glencoe, IL: Free Press, 1963, pp. 111-32.

\section{$\underline{\text { Cases }}$}

Albrecht v. Herald Co.(1968), 88 S. Ct. 869.

Bush v. Gore (2000), 121 S. Ct. 525.

Eastern Enterprises v. Apfel (1998), 118 S. Ct. 2131.

International Olympic Committee v. San Francisco Arts \& Athletics (1986), 789 F.2d 1319.

Khan v. State Oil Co. (1996), 93 F.3d 1358.

San Francisco Arts \& Athletics v. International Olympic Committee (1987), 107 S. Ct. 2971. 
Appendix A, p.1

\section{APPENDIX A (for publication with the main text)}

Proof of Proposition 1. To see that there cannot be any other type of (pure-strategy) equilibrium, suppose that judge $m$ does not write a dissenting opinion for the set of $p_{m}$-values $\left[0, \max \left\{x_{m}, x^{S}\right\}\right)$ plus some additional subset of values $\mathrm{b} \subset\left[\max \left\{\mathrm{x}_{\mathrm{m}}, \mathrm{x}^{\mathrm{S}}\right\}\right]$, 1] (excluding $\mathrm{b}=\left\{\max \left\{\mathrm{x}_{\mathrm{m}}, \mathrm{x}^{\mathrm{S}}\right\}\right\}$; see footnote 26), and writes for the remaining values of $p_{m}$. If all justices would vote to deny cert based on the belief that no opinion came from the set $\left[0, \max \left\{\mathrm{x}_{\mathrm{m}}, \mathrm{x}^{\mathrm{S}}\right\}\right) \cup \mathrm{b}$, then judge $\mathrm{m}$ has an incentive to defect from not writing to writing for some $\mathrm{p}_{\mathrm{m}} \in \mathrm{b}$, since this will provoke cert (since $\max _{\mathrm{i}}\left\{\mathrm{V}_{\mathrm{i}}\left(\mathrm{p}_{\mathrm{M}}\right.\right.$, $\left.\left.\mathrm{p}_{\mathrm{m}}\right)\right\}>0$ for $\left.\mathrm{p}_{\mathrm{m}} \in \mathrm{b}\right)$. On the other hand, if some justice would vote to grant cert based on the belief that no opinion came from the set $\left[0, \max \left\{x_{m}, x^{S}\right\}\right) \cup b$, then judge $m$ has an incentive to defect from writing to not writing for those values of $\mathrm{p}_{\mathrm{m}} \notin\left[0, \max \left\{\mathrm{x}_{\mathrm{m}}, \mathrm{x}^{\mathrm{S}}\right\}\right) \cup \mathrm{b}$. Thus, no such writing strategies on the part of judge $\mathrm{m}$ can be part of a (pure-strategy) equilibrium.

To see that an equilibrium always exists, note that $\mathrm{E}\left\{\mathrm{V}_{\mathrm{i}}\left(\mathrm{p}_{\mathrm{M}}, \mathrm{p}_{\mathrm{m}}\right) \mid \mathrm{p}_{\mathrm{m}} \in[0, \mathrm{x}]\right\}$ is an increasing function of $x$, since $V_{i}\left(p_{M}, p_{m}\right)$ is increasing in $p_{m}$, and $p_{M}$ and $p_{m}$ are affiliated (see Milgrom and Weber [1982], Theorem 5). Thus, when the hypothesis of part (a) holds, then some justice i will vote to grant cert, without an opinion, under the belief that $\mathrm{p}_{\mathrm{m}} \in\left[0, \max \left\{\mathrm{x}_{\mathrm{m}}, \mathrm{x}^{\mathrm{S}}\right\}\right)$, thereby upsetting a Type IIa equilibrium. On the other hand, since $E\left\{\mathrm{~V}_{\mathrm{i}}\left(\mathrm{p}_{\mathrm{M}}, \mathrm{p}_{\mathrm{m}}\right) \mid \mathrm{p}_{\mathrm{m}} \in[0, \mathrm{x}]\right\}$ is an increasing function of $\mathrm{x}$, this same justice will have $\mathrm{E}\left\{\mathrm{V}_{\mathrm{i}}\left(\mathrm{p}_{\mathrm{M}}, \mathrm{p}_{\mathrm{m}}\right) \mid \mathrm{p}_{\mathrm{m}} \in[0,1]\right\}>0$, thus supporting a Type I equilibrium. When the hypothesis of part (b) holds, then no justice will vote to grant cert under the belief that $\mathrm{p}_{\mathrm{m}}$ $\in[0,1]$, upsetting a Type I equilibrium. However, since $\mathrm{E}\left\{\mathrm{V}_{\mathrm{i}}\left(\mathrm{p}_{\mathrm{M}}, \mathrm{p}_{\mathrm{m}}\right) \mid \mathrm{p}_{\mathrm{m}} \in[0, \mathrm{x}]\right\}$ is an increasing function of $x$, no justice will vote to grant cert under the belief that $\mathrm{p}_{\mathrm{m}} \in\left[0, \max \left\{\mathrm{x}_{\mathrm{m}}, \mathrm{x}^{\mathrm{S}}\right\}\right)$ either, thus supporting a Type IIa equilibrium.

Proof of part (a). If judge $m$ uses a strategy of writing if and only if $\mathrm{p}_{\mathrm{m}} \in\left[\max \left\{\mathrm{x}_{\mathrm{m}}, \mathrm{x}^{\mathrm{s}}\right\}, 1\right]$, then upon observing no opinion, the justices infer that $\mathrm{p}_{\mathrm{m}} \in\left[0, \max \left\{\mathrm{x}_{\mathrm{m}}, \mathrm{x}^{\mathrm{S}}\right\}\right)$ and calculate $\mathrm{V}_{\mathrm{i}}\left(\mathrm{p}_{\mathrm{M}},\left[0, \max \left\{\mathrm{x}_{\mathrm{m}}, \mathrm{x}^{\mathrm{S}}\right\}\right)\right)=\mathrm{E}\left\{\mathrm{V}_{\mathrm{i}}\left(\mathrm{p}_{\mathrm{M}}, \mathrm{p}_{\mathrm{m}}\right) \mid \mathrm{p}_{\mathrm{m}} \in\left[0, \max \left\{\mathrm{x}_{\mathrm{m}}, \mathrm{x}^{\mathrm{S}}\right\}\right)\right\}$. If this is positive for at least one justice (as hypothesized in part (a)), then cert will be granted even without a dissenting opinion. But then it will not be optimal for judge $m$ to write for $\mathrm{p}_{\mathrm{m}} \in\left[\max \left\{\mathrm{x}_{\mathrm{m}}, \mathrm{x}^{\mathrm{s}}\right\}, 1\right]$, upsetting a Type IIa equilibrium. However, suppose that judge $m$ uses a strategy of not writing for any $p_{m} \in[0,1]$. In this case, upon observing no dissenting opinion, the justices infer that $\mathrm{p}_{\mathrm{m}} \in[0,1]$, and calculate $\mathrm{V}_{\mathrm{i}}\left(\mathrm{p}_{\mathrm{M}},[0,1]\right)$. Since $\mathrm{V}_{\mathrm{i}}\left(\mathrm{p}_{\mathrm{M}},[0, \mathrm{x})\right)$ is increasing in $\mathrm{x}$, if $\mathrm{V}_{\mathrm{i}}\left(\mathrm{p}_{\mathrm{M}},\left[0, \max \left\{\mathrm{x}_{\mathrm{m}}, \mathrm{x}^{\mathrm{S}}\right\}\right)\right)>0$ for some justice $i$, then $V_{i}\left(p_{M},[0,1]\right)>0$ as well, and thus justice $i$ will vote to grant cert even if judge $m$ never writes a dissenting opinion. Thus a Type I equilibrium exists.

Proof of part (b). If judge $m$ uses a strategy of not writing for any $\mathrm{p}_{\mathrm{m}} \in[0,1]$, then upon observing no opinion, the justices infer that $\mathrm{p}_{\mathrm{m}} \in[0,1]$, and calculate $\mathrm{V}_{\mathrm{i}}\left(\mathrm{p}_{\mathrm{M}},[0,1]\right)$. Under the hypothesis of part (b), $\mathrm{V}_{\mathrm{i}}\left(\mathrm{p}_{\mathrm{M}},[0,1]\right)<0$ for all justices and so none of them will vote to grant cert. But then judge $\mathrm{m}$ will deviate from never writing to writing for $\mathrm{p}_{\mathrm{m}} \in\left[\max \left\{\mathrm{x}_{\mathrm{m}}, \mathrm{x}^{\mathrm{S}}\right\}, 1\right]$, since this will provoke cert. Thus a Type I equilibrium cannot occur. However, suppose that judge $m$ uses a strategy of writing a dissent if and only if $\mathrm{p}_{\mathrm{m}} \in\left[\max \left\{\mathrm{x}_{\mathrm{m}}, \mathrm{x}^{\mathrm{s}}\right\}, 1\right]$. Then upon observing no dissent, the justices infer that $\mathrm{p}_{\mathrm{m}} \in\left[0, \max \left\{\mathrm{x}_{\mathrm{m}}, \mathrm{x}^{\mathrm{S}}\right\}\right)$, and calculate $\mathrm{V}_{\mathrm{i}}\left(\mathrm{p}_{\mathrm{M}},\left[0, \max \left\{\mathrm{x}_{\mathrm{m}}, \mathrm{x}^{\mathrm{S}}\right\}\right)\right)$. Since $\mathrm{V}_{\mathrm{i}}\left(\mathrm{p}_{\mathrm{M}},[0, \mathrm{x})\right)$ is increasing in $\mathrm{x}$, if $\mathrm{V}_{\mathrm{i}}\left(\mathrm{p}_{\mathrm{M}},[0,1]\right)<0$ for all $\mathrm{i}$, then $\mathrm{V}_{\mathrm{i}}\left(\mathrm{p}_{\mathrm{M}},\left[0, \max \left\{\mathrm{x}_{\mathrm{m}}, \mathrm{x}^{\mathrm{S}}\right\}\right)\right)<0$ for all $\mathrm{i}$ as well, which implies that no justice will vote to grant cert without a dissenting opinion. This supports a Type IIa equilibrium. 
Proof of part (c). If judge $m$ uses a strategy of not writing for any $\mathrm{p}_{\mathrm{m}} \in[0,1]$, then upon observing no opinion, the justices infer that $\mathrm{p}_{\mathrm{m}} \in[0,1]$, and calculate $\mathrm{V}_{\mathrm{i}}\left(\mathrm{p}_{\mathrm{M}},[0,1]\right)$. Under the hypothesis of part (c), $\mathrm{V}_{\mathrm{i}}\left(\mathrm{p}_{\mathrm{M}},[0,1]\right) \geq 0$ for at least one justice $\mathrm{i}$, so this justice will vote to grant cert even without a dissenting opinion. In this case, it will be optimal for judge $m$ not to write for any $p_{m} \in[0,1]$. Thus a Type I equilibrium exists. If judge $m$ uses a strategy of writing a dissenting opinion if and only if $\mathrm{p}_{\mathrm{m}} \in\left[\max \left\{\mathrm{x}_{\mathrm{m}}, \mathrm{x}^{\mathrm{S}}\right\}, 1\right]$, then upon observing no opinion, the justices infer that $\mathrm{p}_{\mathrm{m}} \in$ $\left[0, \max \left\{x_{m}, x^{S}\right\}\right)$, and calculate $V_{i}\left(p_{M},\left[0, \max \left\{x_{m}, x^{S}\right\}\right)\right)$. Under the hypothesis of part (c), this expression is non-positive for all $\mathrm{i}$, so justice $\mathrm{i}$ will not vote to grant cert without a dissenting opinion. Judge $\mathrm{m}$ will be willing to write for $\mathrm{p}_{\mathrm{m}} \in\left[\max \left\{\mathrm{x}_{\mathrm{m}}, \mathrm{x}^{\mathrm{S}}\right\}, 1\right]$ if doing so will provoke cert, which is the case. Thus a Type IIa equilibrium exists. QED.

Claim associated with discussion preceding Figure 3.

1) $\mathrm{V}_{\mathrm{i}}\left(\mathrm{p}_{\mathrm{M}},\left[0, \mathrm{x}_{\mathrm{m}}\right) ; 0\right)>0$; and 2) $\left.\mathrm{V}_{\mathrm{i}}\left(\mathrm{p}_{\mathrm{M}},\left[0, \mathrm{x}_{\mathrm{m}}\right) ; \mathrm{k}_{\mathrm{SC} 2}\right)<0 ; 3\right) \mathrm{V}_{\mathrm{i}}\left(\mathrm{p}_{\mathrm{M}},\left[0, \mathrm{x}_{\mathrm{i}}\left(\mathrm{k}_{\mathrm{SC}}\right)\right) ; \mathrm{k}_{\mathrm{SC}}\right)<0$.

Let us denote the dependence of the expression $\mathrm{V}_{\mathrm{i}}\left(\mathrm{p}_{\mathrm{M}},\left[0, \max \left\{\mathrm{x}_{\mathrm{m}}, \mathrm{x}_{\mathrm{i}}\right\}\right)\right)$ on $\mathrm{k}_{\mathrm{SC}}$ as $\mathrm{V}_{\mathrm{i}}\left(\mathrm{p}_{\mathrm{M}},\left[0, \max \left\{\mathrm{x}_{\mathrm{m}}\right.\right.\right.$, $\left.\left.\left.\mathrm{x}_{\mathrm{i}}\left(\mathrm{k}_{\mathrm{SC}}\right)\right\}\right) ; \mathrm{k}_{\mathrm{SC}}\right)$, since $\mathrm{k}_{\mathrm{SC}}$ enters additively with a negative sign and enters again through $\mathrm{x}_{\mathrm{i}}\left(\mathrm{k}_{\mathrm{SC}}\right)$. As noted in the text, for $\mathrm{k}_{\mathrm{SC}} \in\left[0, \mathrm{k}_{\mathrm{SC}}\right], \mathrm{V}_{\mathrm{i}}\left(\mathrm{p}_{\mathrm{M}},\left[0, \max \left\{\mathrm{x}_{\mathrm{m}}, \mathrm{x}_{\mathrm{i}}\left(\mathrm{k}_{\mathrm{SC}}\right)\right\}\right) ; \mathrm{k}_{\mathrm{SC}}\right)=\mathrm{V}_{\mathrm{i}}\left(\mathrm{p}_{\mathrm{M}},\left[0, \mathrm{x}_{\mathrm{m}}\right) ; \mathrm{k}_{\mathrm{SC}}\right)$; on the other hand, for $\mathrm{k}_{\mathrm{SC}} \in\left[\mathrm{k}_{\mathrm{SC} 2}, \mathrm{k}_{\mathrm{SC} 3}\right], \mathrm{V}_{\mathrm{i}}\left(\mathrm{p}_{\mathrm{M}},\left[0, \max \left\{\mathrm{x}_{\mathrm{m}}, \mathrm{x}_{\mathrm{i}}\left(\mathrm{k}_{\mathrm{SC}}\right)\right\}\right) ; \mathrm{k}_{\mathrm{SC}}\right)=\mathrm{V}_{\mathrm{i}}\left(\mathrm{p}_{\mathrm{M}},\left[0, \mathrm{x}_{\mathrm{i}}\left(\mathrm{k}_{\mathrm{SC}}\right)\right) ; \mathrm{k}_{\mathrm{SC}}\right)$.

Proof of Claim Part 1. Since $\mathrm{V}_{\mathrm{i}}\left(\mathrm{p}_{\mathrm{M}}, 0 ; 0\right)=0$ (this follows from the fact that $\left.\mathrm{x}_{\mathrm{i}}(0)=0\right)$ and $\mathrm{V}_{\mathrm{i}}$ is increasing in $\mathrm{p}_{\mathrm{m}}$, it follows that $\mathrm{V}_{\mathrm{i}}\left(\mathrm{p}_{\mathrm{M}}, \mathrm{p}_{\mathrm{m}} ; 0\right)>0$ for all $\mathrm{p}_{\mathrm{m}} \in(0,1]$. Thus, $\mathrm{V}_{\mathrm{i}}\left(\mathrm{p}_{\mathrm{M}},\left[0, \mathrm{x}_{\mathrm{m}}\right) ; 0\right)>0$.

Proof of Claim Part 2. Since $\mathrm{V}_{\mathrm{i}}\left(\mathrm{p}_{\mathrm{M}}, \mathrm{x}_{\mathrm{m}} ; \mathrm{k}_{\mathrm{SC} 2}\right)=0$ (this follows from the fact that $\left.\mathrm{x}_{\mathrm{i}}\left(\mathrm{k}_{\mathrm{SC} 2}\right)=\mathrm{x}_{\mathrm{m}}\right)$ and $\mathrm{V}_{\mathrm{i}}$ is increasing in $\mathrm{p}_{\mathrm{m}}$, it follows that $\mathrm{V}_{\mathrm{i}}\left(\mathrm{p}_{\mathrm{M}}, \mathrm{p}_{\mathrm{m}} ; \mathrm{k}_{\mathrm{SC} 2}\right)<0$ for all $\mathrm{p}_{\mathrm{m}} \in\left[0, \mathrm{x}_{\mathrm{m}}\right)$. Thus $\mathrm{V}_{\mathrm{i}}\left(\mathrm{p}_{\mathrm{M}},\left[0, \mathrm{x}_{\mathrm{m}}\right)\right.$; $\left.\mathrm{k}_{\mathrm{SC} 2}\right)<0$.

Proof of Claim Part 3. Since $\mathrm{V}_{\mathrm{i}}\left(\mathrm{p}_{\mathrm{M}}, \mathrm{x}_{\mathrm{i}}\left(\mathrm{k}_{\mathrm{SC}}\right) ; \mathrm{k}_{\mathrm{SC}}\right)=0$ (this follows from the definition of $\mathrm{x}_{\mathrm{i}}$ ) and, since $\mathrm{V}_{\mathrm{i}}$ is increasing in $\mathrm{p}_{\mathrm{m}}$, it follows that $\mathrm{V}_{\mathrm{i}}\left(\mathrm{p}_{\mathrm{M}}, \mathrm{p}_{\mathrm{m}} ; \mathrm{k}_{\mathrm{SC}}\right)<0$ for all $\mathrm{p}_{\mathrm{m}} \in\left[0, \mathrm{x}_{\mathrm{i}}\left(\mathrm{k}_{\mathrm{SC}}\right)\right)$. Thus $\mathrm{V}_{\mathrm{i}}\left(\mathrm{p}_{\mathrm{M}},\left[0, \mathrm{x}_{\mathrm{i}}\left(\mathrm{k}_{\mathrm{SC}}\right)\right) ; \mathrm{k}_{\mathrm{SC}}\right)<0$. QED

Proof of Proposition 3. Suppose that $\left[\mathrm{x}_{\mathrm{m}}, \mathrm{x}_{\mathrm{i}}\right]$ is non-empty; if this set is empty, then $\mathrm{V}_{\mathrm{i}}\left(\mathrm{p}_{\mathrm{M}},\left[0, \mathrm{x}_{\mathrm{m}}\right)\right.$ $\left.\cup\left(\mathrm{x}_{\mathrm{i}}, 1\right]\right)=\mathrm{V}_{\mathrm{i}}\left(\mathrm{p}_{\mathrm{M}},[0,1]\right)$ and the proof is trivial. To see that there cannot be any other type of (purestrategy) equilibrium, suppose that judge $m$ does not write a dissenting opinion for the set of $p_{m}{ }^{-}$ values $\left[0, x_{m}\right) \cup\left(x_{i}, 1\right]$ plus some additional subset of values $b \subset\left[x_{m}, x_{i}\right]$ (excluding $b=\left\{x_{m}\right\}$ and $\mathrm{b}=\left\{\mathrm{x}_{\mathrm{i}}\right\}$; see footnote 29), and writes for the remaining values of $\mathrm{p}_{\mathrm{m}}$. If justice $\mathrm{i}$ would vote to deny cert based on the belief that no opinion came from the set $\left[0, x_{m}\right) \cup\left(x_{i}, 1\right] \cup b$, then judge $m$ has an incentive to defect from not writing to writing for some $p_{m} \in b$, since this will provoke cert (since $\mathrm{V}_{\mathrm{i}}\left(\mathrm{p}_{\mathrm{M}}, \mathrm{p}_{\mathrm{m}}\right)>0$ for $\left.\mathrm{p}_{\mathrm{m}} \in \mathrm{b}\right)$. On the other hand, if justice $\mathrm{i}$ would vote to grant cert based on the belief that no opinion came from the set $\left[0, x_{m}\right) \cup\left(x_{i}, 1\right] \cup b$, then judge $m$ has an incentive to defect from writing to not writing for those values of $\mathrm{p}_{\mathrm{m}} \notin\left[0, \mathrm{x}_{\mathrm{m}}\right) \cup\left(\mathrm{x}_{\mathrm{i}}, 1\right] \cup \mathrm{b}$. Thus, no such writing strategies on the part of judge $\mathrm{m}$ can be part of a (pure-strategy) equilibrium.

The reason we are able to establish existence in this case is that $\mathrm{E}\left\{\mathrm{V}_{\mathrm{i}}\left(\mathrm{p}_{\mathrm{M}}, \mathrm{p}_{\mathrm{m}}\right) \mid \mathrm{p}_{\mathrm{m}} \in[0,1]\right\}$ $=\mathrm{E}\left\{\mathrm{V}_{\mathrm{i}}\left(\mathrm{p}_{\mathrm{M}}, \mathrm{p}_{\mathrm{m}}\right) \mid \mathrm{p}_{\mathrm{m}} \in\left[0, \mathrm{x}_{\mathrm{m}}\right) \cup\left(\mathrm{x}_{\mathrm{i}}, 1\right]\right\} \operatorname{Pr}\left\{\mathrm{p}_{\mathrm{m}} \in\left[0, \mathrm{x}_{\mathrm{m}}\right) \cup\left(\mathrm{x}_{\mathrm{i}}, 1\right]\right\}+\mathrm{E}\left\{\mathrm{V}_{\mathrm{i}}\left(\mathrm{p}_{\mathrm{M}}, \mathrm{p}_{\mathrm{m}}\right) \mid \mathrm{p}_{\mathrm{m}} \in\left[\mathrm{x}_{\mathrm{m}}, \mathrm{x}_{\mathrm{i}}\right]\right\} \operatorname{Pr}\left\{\mathrm{p}_{\mathrm{m}}\right.$ 
$\left.\in\left[\mathrm{x}_{\mathrm{m}}, \mathrm{x}_{\mathrm{i}}\right]\right\}$. Notice that the expression $\mathrm{E}\left\{\mathrm{V}_{\mathrm{i}}\left(\mathrm{p}_{\mathrm{M}}, \mathrm{p}_{\mathrm{m}}\right) \mid \mathrm{p}_{\mathrm{m}} \in\left[\mathrm{x}_{\mathrm{m}}, \mathrm{x}_{\mathrm{i}}\right]\right\} \geq 0$, when $\left[\mathrm{x}_{\mathrm{m}}, \mathrm{x}_{\mathrm{i}}\right]$ is non-empty, since $V_{i}\left(p_{M}, p_{m}\right) \geq 0$ for $p_{m} \in\left[x_{m}, x_{i}\right]$, as can be seen in Figure 4(a). Thus, if $E\left\{V_{i}\left(p_{M}, p_{m}\right) \mid p_{m} \in[0\right.$, $\left.\left.\mathrm{x}_{\mathrm{m}}\right) \cup\left(\mathrm{x}_{\mathrm{i}}, 1\right]\right\}>0$ (upsetting a Type IIb equilibrium), then $\mathrm{E}\left\{\mathrm{V}_{\mathrm{i}}\left(\mathrm{p}_{\mathrm{M}}, \mathrm{p}_{\mathrm{m}}\right) \mid \mathrm{p}_{\mathrm{m}} \in[0,1]\right\}>0$ (supporting a Type I equilibrium). Similarly, if $\mathrm{E}\left\{\mathrm{V}_{\mathrm{i}}\left(\mathrm{p}_{\mathrm{M}}, \mathrm{p}_{\mathrm{m}}\right) \mid \mathrm{p}_{\mathrm{m}} \in[0,1]\right\}<0$ (upsetting a Type I equilibrium), then $\mathrm{E}\left\{\mathrm{V}_{\mathrm{i}}\left(\mathrm{p}_{\mathrm{M}}, \mathrm{p}_{\mathrm{m}}\right) \mid \mathrm{p}_{\mathrm{m}} \in\left[0, \mathrm{x}_{\mathrm{m}}\right) \cup\left(\mathrm{x}_{\mathrm{i}}, 1\right]\right\}<0$ (supporting a Type IIb equilibrium). Thus, if justice $\mathrm{i}$ upsets one type of equilibrium, she guarantees that the other exists. If $\left[\mathrm{x}_{\mathrm{m}}, \mathrm{x}_{\mathrm{i}}\right]$ is empty then $\operatorname{Pr}\left\{\mathrm{p}_{\mathrm{m}}\right.$ $\left.\in\left[\mathrm{x}_{\mathrm{m}}, \mathrm{x}_{\mathrm{i}}\right]\right\}=0$ and the same argument holds.

Proof of part (a). If judge $m$ uses a strategy of writing if and only if $\mathrm{p}_{\mathrm{m}} \in\left[\mathrm{x}_{\mathrm{m}}, \mathrm{x}_{\mathrm{i}}\right]$, then upon observing no opinion, justice $\mathrm{i}$ infers that $\mathrm{p}_{\mathrm{m}} \in\left[0, \mathrm{x}_{\mathrm{m}}\right) \cup\left(\mathrm{x}_{\mathrm{i}}, 1\right]$ and calculates $\mathrm{V}_{\mathrm{i}}\left(\mathrm{p}_{\mathrm{M}},\left[0, \mathrm{x}_{\mathrm{m}}\right) \cup\left(\mathrm{x}_{\mathrm{i}}, 1\right]\right)$ $=\mathrm{E}\left\{\mathrm{V}_{\mathrm{i}}\left(\mathrm{p}_{\mathrm{M}}, \mathrm{p}_{\mathrm{m}}\right) \mid \mathrm{p}_{\mathrm{m}} \in\left[0, \mathrm{x}_{\mathrm{m}}\right) \cup\left(\mathrm{x}_{\mathrm{i}}, 1\right]\right\}$. If this is positive for justice $\mathrm{i}$ (as hypothesized in part (a)), then cert will be granted even without a dissenting opinion. But then it will not be optimal for judge $\mathrm{m}$ to write for $\mathrm{p}_{\mathrm{m}} \in\left[\mathrm{x}_{\mathrm{m}}, \mathrm{x}_{\mathrm{i}}\right]$, upsetting a Type IIb equilibrium. However, suppose that judge $\mathrm{m}$ uses a strategy of not writing for any $\mathrm{p}_{\mathrm{m}} \in[0,1]$. In this case, upon observing no dissenting opinion, justice $\mathrm{i}$ infers that $\mathrm{p}_{\mathrm{m}} \in[0,1]$, and calculates $\mathrm{V}_{\mathrm{i}}\left(\mathrm{p}_{\mathrm{M}},[0,1]\right)$. Notice that:

$$
\begin{aligned}
\mathrm{V}_{\mathrm{i}}\left(\mathrm{p}_{\mathrm{M}},[0,1]\right)=\mathrm{V}_{\mathrm{i}}\left(\mathrm{p}_{\mathrm{M}},\left[0, \mathrm{x}_{\mathrm{m}}\right) \cup\left(\mathrm{x}_{\mathrm{i}}, 1\right]\right) & \operatorname{Pr}\left\{\mathrm{p}_{\mathrm{m}} \in\left[0, \mathrm{x}_{\mathrm{m}}\right) \cup\left(\mathrm{x}_{\mathrm{i}}, 1\right]\right\} \\
& +\mathrm{V}_{\mathrm{i}}\left(\mathrm{p}_{\mathrm{M}},\left[\mathrm{x}_{\mathrm{m}}, \mathrm{x}_{\mathrm{i}}\right]\right) \operatorname{Pr}\left\{\mathrm{p}_{\mathrm{m}} \in\left[\mathrm{x}_{\mathrm{m}}, \mathrm{x}_{\mathrm{i}}\right]\right\} .
\end{aligned}
$$

The expression $\mathrm{V}_{\mathrm{i}}\left(\mathrm{p}_{\mathrm{M}},\left[\mathrm{x}_{\mathrm{m}}, \mathrm{x}_{\mathrm{i}}\right]\right)=\mathrm{E}\left\{\mathrm{V}_{\mathrm{i}}\left(\mathrm{p}_{\mathrm{M}}, \mathrm{p}_{\mathrm{m}}\right) \mid \mathrm{p}_{\mathrm{m}} \in\left[\mathrm{x}_{\mathrm{m}}, \mathrm{x}_{\mathrm{i}}\right]\right\} \geq 0$ since $\mathrm{V}_{\mathrm{i}}\left(\mathrm{p}_{\mathrm{M}}, \mathrm{p}_{\mathrm{m}}\right) \geq 0$ for $\mathrm{p}_{\mathrm{m}} \in$ $\left[\mathrm{x}_{\mathrm{m}}, \mathrm{x}_{\mathrm{i}}\right]$, as can be seen in Figure $4(\mathrm{a})$. Thus, if $\mathrm{V}_{\mathrm{i}}\left(\mathrm{p}_{\mathrm{M}},\left[0, \mathrm{x}_{\mathrm{m}}\right) \cup\left(\mathrm{x}_{\mathrm{i}}, 1\right]\right)>0$, then so is $\mathrm{V}_{\mathrm{i}}\left(\mathrm{p}_{\mathrm{M}},[0,1]\right)$ $>0$, and thus a Type I equilibrium exists.

Proof of part (b). If judge $m$ uses a strategy of not writing for any $\mathrm{p}_{\mathrm{m}} \in[0,1]$, then upon observing no opinion, justice $i$ infers that $\mathrm{p}_{\mathrm{m}} \in[0,1]$, and calculates $\mathrm{V}_{\mathrm{i}}\left(\mathrm{p}_{\mathrm{M}},[0,1]\right)$. Under the hypothesis of part (b), $\mathrm{V}_{\mathrm{i}}\left(\mathrm{p}_{\mathrm{M}},[0,1]\right)<0$ and so cert is denied without an opinion. But then judge $\mathrm{m}$ will deviate from never writing to writing for $\mathrm{p}_{\mathrm{m}} \in\left[\mathrm{x}_{\mathrm{m}}, \mathrm{x}_{\mathrm{i}}\right]$, since this will provoke cert. Thus a Type $\mathrm{I}$ equilibrium cannot occur. However, suppose that judge m uses a strategy of writing a dissent if and only if $\mathrm{p}_{\mathrm{m}} \in\left[\mathrm{x}_{\mathrm{m}}, \mathrm{x}_{\mathrm{i}}\right]$. Then upon observing no dissent, the justices infer that $\mathrm{p}_{\mathrm{m}} \in\left[0, \mathrm{x}_{\mathrm{m}}\right) \cup\left(\mathrm{x}_{\mathrm{i}}, 1\right]$, and calculate $\mathrm{V}_{\mathrm{i}}\left(\mathrm{p}_{\mathrm{M}},\left[0, \mathrm{x}_{\mathrm{m}}\right) \cup\left(\mathrm{x}_{\mathrm{i}}, 1\right]\right)$. Referring to equation (A.1), we see that if $\mathrm{V}_{\mathrm{i}}\left(\mathrm{p}_{\mathrm{M}},[0,1]\right)<0$, then so is $\mathrm{V}_{\mathrm{i}}\left(\mathrm{p}_{\mathrm{M}},\left[0, \mathrm{x}_{\mathrm{m}}\right) \cup\left(\mathrm{x}_{\mathrm{i}}, 1\right]\right)<0$, and thus a Type IIb equilibrium exists.

Proof of part (c). If judge $m$ uses a strategy of not writing for any $\mathrm{p}_{\mathrm{m}} \in[0,1]$, then upon observing no opinion, justice $i$ infers that $\mathrm{p}_{\mathrm{m}} \in[0,1]$, and calculates $\mathrm{V}_{\mathrm{i}}\left(\mathrm{p}_{\mathrm{M}},[0,1]\right)$. Under the hypothesis of part (c), $\mathrm{V}_{\mathrm{i}}\left(\mathrm{p}_{\mathrm{M}},[0,1]\right) \geq 0$, so justice $\mathrm{i}$ will vote to grant cert even without a dissenting opinion. In this case, it will be optimal for judge $m$ not to write for any $p_{m} \in[0,1]$. Thus a Type I equilibrium exists. If judge $m$ uses a strategy of writing a dissenting opinion if and only if $\mathrm{p}_{\mathrm{m}} \in\left[\mathrm{x}_{\mathrm{m}}, \mathrm{x}_{\mathrm{i}}\right]$, then upon observing no opinion, justice $i$ infers that $\mathrm{p}_{\mathrm{m}} \in\left[0, \mathrm{x}_{\mathrm{m}}\right) \cup\left(\mathrm{x}_{\mathrm{i}}, 1\right]$, and calculates $\mathrm{V}_{\mathrm{i}}\left(\mathrm{p}_{\mathrm{M}},\left[0, \mathrm{x}_{\mathrm{m}}\right)\right.$ $\left.\cup\left(\mathrm{x}_{\mathrm{i}}, 1\right]\right)$. Under the hypothesis of part (c), this expression is non-positive, so justice $\mathrm{i}$ will vote to deny cert without a dissenting opinion. Judge $\mathrm{m}$ will be willing to write for $\mathrm{p}_{\mathrm{m}} \in\left[\mathrm{x}_{\mathrm{m}}, \mathrm{x}_{\mathrm{i}}\right]$ if doing so will provoke cert, which is the case. Thus a Type IIb equilibrium exists. QED.

Proposition $3^{\prime}$ (multiple unsympathetic and persuadable justices). There are only two possible types 
of (pure-strategy) equilibrium for the case of one to three unsympathetic and persuadable justices, assuming that any remaining justices are predisposed to deny cert.

(a) If $\max _{\mathrm{i}}\left\{\mathrm{V}_{\mathrm{i}}\left(\mathrm{p}_{\mathrm{M}},\left[0, \mathrm{x}_{\mathrm{m}}\right) \cup\left(\mathrm{x}^{\mathrm{U}}, 1\right]\right)\right\}=\max _{\mathrm{i}}\left\{\mathrm{E}\left\{\mathrm{V}_{\mathrm{i}}\left(\mathrm{p}_{\mathrm{M}}, \mathrm{p}_{\mathrm{m}}\right) \mid \mathrm{p}_{\mathrm{m}} \in\left[0, \mathrm{x}_{\mathrm{m}}\right) \cup\left(\mathrm{x}^{\mathrm{U}}, 1\right]\right\}\right\} \leq 0$, then a Type IIb equilibrium exists.

(b) If $\max _{\mathrm{i}}\left\{\mathrm{V}_{\mathrm{i}}\left(\mathrm{p}_{\mathrm{M}},[0,1]\right)\right\}=\max _{\mathrm{i}}\left\{\mathrm{E}\left\{\mathrm{V}_{\mathrm{i}}\left(\mathrm{p}_{\mathrm{M}}, \mathrm{p}_{\mathrm{m}}\right) \mid \mathrm{p}_{\mathrm{m}} \in[0,1]\right\}\right\} \geq 0$, then a Type I equilibrium exists.

Proof of Proposition 3'. This proof is available in Appendix B.

Comment. Proposition 3' is weaker than Proposition 3 because the argument involving equation (A.1) does not extend to multiple unsympathetic justices, since it need not be true that $\mathrm{V}_{\mathrm{i}}\left(\mathrm{p}_{\mathrm{M}},\left[\mathrm{x}_{\mathrm{m}}, \mathrm{x}^{\mathrm{U}}\right]\right) \geq 0$ for all $\mathrm{i}$. Thus different justices can upset a Type I versus a Type IIb equilibrium. The hypothesis that $\mathrm{V}_{\mathrm{i}}\left(\mathrm{p}_{\mathrm{M}},\left[0, \mathrm{x}_{\mathrm{m}}\right) \cup\left(\mathrm{x}_{\mathrm{i}}, 1\right]\right)>0$ for some $\mathrm{i}$ (upsetting a Type IIb equilibria) does not imply that $\mathrm{V}_{\mathrm{i}}\left(\mathrm{p}_{\mathrm{M}},[0,1]\right) \geq 0$. Similarly, the hypothesis that $\mathrm{V}_{\mathrm{i}}\left(\mathrm{p}_{\mathrm{M}},[0,1]\right)<0$ for all $\mathrm{i}$ (upsetting a Type I equilibrium) does not imply that $\mathrm{V}_{\mathrm{i}}\left(\mathrm{p}_{\mathrm{M}},\left[0, \mathrm{x}_{\mathrm{m}}\right) \cup\left(\mathrm{x}^{\mathrm{U}}, 1\right]\right) \leq 0$ for all $\mathrm{i}$. Consequently, it is possible for neither of the hypotheses to hold, in which case there is no purestrategy equilibrium. The nature of the mixing needed to support a mixed-strategy equilibrium is that one or more justices must randomize after receiving no dissenting opinion. 
Appendix B, p.1

\section{APPENDIX B (to be available on the web)}

\section{Derivation of Posterior Estimator of $\mathrm{p}_{\mathrm{SC}}$}

The joint density on $\left(\mathrm{p}_{\mathrm{M}}, \mathrm{p}_{\mathrm{m}}, \mathrm{p}_{\mathrm{SC}}\right)$ is denoted $\mathrm{h}\left(\mathrm{p}_{\mathrm{M}}, \mathrm{p}_{\mathrm{m}}, \mathrm{p}_{\mathrm{SC}}\right)$, which is taken to be continuous and have positive support on its entire domain. There are two possible reports (opinions, $\mathrm{s}_{\mathrm{m}}$ ) from $\mathrm{m}$, namely $\mathrm{p}_{\mathrm{m}}$ and $\varnothing$ (no opinion), so beliefs $\mathrm{b}\left(\mathrm{p}_{\mathrm{M}}, \mathrm{s}_{\mathrm{m}}\right)$ are either (respectively), $\mathrm{p}_{\mathrm{m}}$ or $\mathrm{b}\left(\mathrm{p}_{\mathrm{M}}, \varnothing\right)$. Thus, the estimator of $p_{\mathrm{SC}}$ used by each justice (and by judge $m$ when forecasting the behavior of every justice) for these two reports is either (respectively) $\rho\left(p_{M}, p_{m}\right)$ or $\rho\left(p_{M}, b\left(p_{M}, \varnothing\right)\right)$. We provide the general form for these estimators below.

For notational convenience we derive the following conditional densities (where $\mathrm{I} \equiv[0,1]$ and $\left.\mathrm{J} \equiv \mathrm{b}\left(\mathrm{p}_{\mathrm{M}}, \varnothing\right)\right)$.

$$
\begin{array}{ll}
\mathrm{g}\left(\mathrm{p}_{\mathrm{SC}} \mid \mathrm{p}_{\mathrm{M}}, \mathrm{p}_{\mathrm{m}}\right) & \equiv \mathrm{h}\left(\mathrm{p}_{\mathrm{M}}, \mathrm{p}_{\mathrm{m}}, \mathrm{p}_{\mathrm{SC}}\right)\left[\int_{\mathrm{I}} \mathrm{h}\left(\mathrm{p}_{\mathrm{M}}, \mathrm{p}_{\mathrm{m}}, \mathrm{u}\right) \mathrm{du}\right]^{-1}, \\
\mathrm{f}\left(\mathrm{p}_{\mathrm{m}} \mid \mathrm{p}_{\mathrm{M}}\right) & \equiv \int_{\mathrm{I}} \mathrm{h}\left(\mathrm{p}_{\mathrm{M}}, \mathrm{p}_{\mathrm{m}}, \mathrm{t}\right)\left[\int_{\mathrm{I}} \int_{\mathrm{I}} \mathrm{h}\left(\mathrm{p}_{\mathrm{M}}, \mathrm{u}, \mathrm{z}\right) \mathrm{du} \mathrm{dz}\right]^{-1} \mathrm{dt} .
\end{array}
$$

Thus, g provides the conditional probability of $\mathrm{P}$ winning his case at $\mathrm{SC}$ (given that it is heard), conditional on the values of $\mathrm{p}_{\mathrm{M}}$ and $\mathrm{p}_{\mathrm{m}}$, while $\mathrm{f}$ provides the conditional probability $\mathrm{p}_{\mathrm{m}}$ given the value of $\mathrm{p}_{\mathrm{M}}$.

Using these we find that:

and

$$
\rho\left(p_{M}, p_{m}\right) \quad=\int_{I} p g\left(p \mid p_{M}, p_{m}\right) f\left(p_{m} \mid p_{M}\right) d p
$$

$$
\rho\left(p_{M}, b\left(p_{M}, \varnothing\right)\right)=\int_{J} \int_{I} p g\left(p \mid p_{M}, q\right) f\left(q \mid p_{M}\right)\left[\int_{J} f\left(t \mid p_{M}\right) d t\right]^{-1} d q d p .
$$

Thus, $\rho$ is the expected value of $p_{S C}$ given M's opinion $\left(p_{M}\right)$ and either the reported value $p_{m}$ (if $m$ wrote an opinion) or the beliefs $b\left(\mathrm{p}_{\mathrm{M}}, \varnothing\right)$ about $\mathrm{p}_{\mathrm{m}}$ if $\mathrm{m}$ provided no opinion.

Lemma 1. If justice $i$ is both sympathetic and persuadable, then $\gamma_{i}^{P}>k_{S C}>\gamma_{i}^{R}$. If justice $i$ is unsympathetic and persuadable, then $\gamma_{i}^{R}>k_{S C}>\gamma_{i}^{P}$.

Proof of Lemma 1. We can write $\mathrm{V}_{\mathrm{i}}\left(\mathrm{p}_{\mathrm{M}}, \mathrm{p}_{\mathrm{m}}\right)$ as $\rho\left(\mathrm{p}_{\mathrm{M}}, \mathrm{p}_{\mathrm{m}}\right)\left(\gamma_{\mathrm{i}}^{\mathrm{P}}-\mathrm{k}_{\mathrm{SC}}\right)+\left(1-\rho\left(\mathrm{p}_{\mathrm{M}}, \mathrm{p}_{\mathrm{m}}\right)\right)\left(\gamma_{\mathrm{i}}^{\mathrm{R}}-\mathrm{k}_{\mathrm{SC}}\right)$. Sympathetic means that $\left(\gamma_{i}^{P}-\gamma_{i}^{R}\right)>0$ while persuadable means that $\left(\gamma_{i}^{P}-k_{S C}\right)$ and $\left(\gamma_{i}^{R}-k_{S C}\right)$ are of opposite sign, so that if justice $i$ is both sympathetic and persuadable, then $\gamma_{\mathrm{i}}^{\mathrm{P}}>\mathrm{k}_{\mathrm{SC}}>\gamma_{\mathrm{i}}^{\mathrm{R}}$. If justice $\mathrm{i}$ is unsympathetic then $\left(\gamma_{\mathrm{i}}^{\mathrm{P}}-\gamma_{\mathrm{i}}^{\mathrm{R}}\right)<0$, so that being both unsympathetic and persuadable implies that $\gamma_{\mathrm{i}}^{\mathrm{R}}>\mathrm{k}_{\mathrm{SC}}>\gamma_{\mathrm{i}}^{\mathrm{P}}$. QED

Proof of Proposition 2. Recall that justice $i$ is sympathetic and persuadable, so $\left(\gamma_{i}^{P}-\gamma_{i}^{R}\right)>0$. (a) The critical value $x_{m}$ is defined implicitly by the equation $\rho\left(p_{M}, x_{m}\right)=\left[u^{s W}-u^{W}+k_{A C}\right] /\left[u^{B}-u^{W}\right]$, where $\rho\left(\mathrm{p}_{\mathrm{M}}, \mathrm{p}_{\mathrm{m}}\right)$ is strictly increasing in both arguments. First note that $\mathrm{x}_{\mathrm{m}}$ is independent of $\mathrm{u}^{\mathrm{SB}}, \mathrm{k}_{\mathrm{SC}}$, $\alpha_{i}^{\mathrm{P}}$ and $\alpha_{\mathrm{i}}^{\mathrm{R}}$. Differentiating and collecting terms implies:

(a.1) $\mathrm{dx}_{\mathrm{m}} / \mathrm{dp}_{\mathrm{M}}=-\left(\partial \rho / \partial \mathrm{p}_{\mathrm{M}}\right) /\left(\partial \rho / \partial \mathrm{p}_{\mathrm{m}}\right)<0$.

(a.2) $\mathrm{dx}_{\mathrm{m}} / \mathrm{du}^{\mathrm{B}}=-\rho /\left(\mathrm{u}^{\mathrm{B}}-\mathrm{u}^{\mathrm{W}}\right)\left(\partial \rho / \partial \mathrm{p}_{\mathrm{m}}\right)<0$.

(a.3) $\mathrm{dx}_{\mathrm{m}} / \mathrm{du}^{\mathrm{SW}}=1 /\left(\mathrm{u}^{\mathrm{B}}-\mathrm{u}^{\mathrm{W}}\right)\left(\partial \rho / \partial \mathrm{p}_{\mathrm{m}}\right)>0$.

(a.4) $\mathrm{dx}_{\mathrm{m}} / \mathrm{du}^{\mathrm{W}}=-(1-\rho) /\left(\mathrm{u}^{\mathrm{B}}-\mathrm{u}^{\mathrm{W}}\right)\left(\partial \rho / \partial \mathrm{p}_{\mathrm{m}}\right)<0$.

(a.5) $\mathrm{dx}_{\mathrm{m}} / \mathrm{dk}_{\mathrm{AC}}=1 /\left(\mathrm{u}^{\mathrm{B}}-\mathrm{u}^{\mathrm{W}}\right)\left(\partial \rho / \partial \mathrm{p}_{\mathrm{m}}\right)>0$.

(b) The critical value $x_{i}$ is defined implicitly by the equation $V_{i}\left(p_{m}, x_{i}\right)=\rho\left(p_{M}, x_{i}\right)\left(\gamma_{i}^{P}-\gamma_{i}^{R}\right)+\gamma_{i}^{R}-$ 
$\mathrm{k}_{\mathrm{SC}}=0$ or, equivalently, $\mathrm{V}_{\mathrm{i}}\left(\mathrm{p}_{\mathrm{m}}, \mathrm{x}_{\mathrm{i}}\right)=\rho\left(\mathrm{p}_{\mathrm{M}}, \mathrm{x}_{\mathrm{i}}\right) \gamma_{\mathrm{i}}^{\mathrm{P}}+\left(1-\rho\left(\mathrm{p}_{\mathrm{m}}, \mathrm{x}_{\mathrm{i}}\right)\right) \gamma_{\mathrm{i}}^{\mathrm{R}}-\mathrm{k}_{\mathrm{SC}}=0$. First note that $\mathrm{x}_{\mathrm{i}}$ is independent of $\mathrm{k}_{\mathrm{AC}}$. Differentiating and collecting terms, taking into account how $\gamma_{\mathrm{i}}^{\mathrm{P}}$ and $\gamma_{\mathrm{i}}^{\mathrm{R}}$ depend on $\mathrm{u}^{\mathrm{B}}, \mathrm{u}^{\mathrm{SB}}, \mathrm{u}^{\mathrm{SW}}, \mathrm{u}^{\mathrm{W}}, \alpha_{\mathrm{i}}^{\mathrm{P}}$ and $\alpha_{\mathrm{i}}^{\mathrm{R}}$, implies:

(b.1) $\mathrm{dx}_{\mathrm{i}} / \mathrm{dp}_{\mathrm{M}}=-\left(\partial \rho / \partial \mathrm{p}_{\mathrm{M}}\right) /\left(\partial \rho / \partial \mathrm{p}_{\mathrm{m}}\right)<0$.

(b.2) $\mathrm{dx}_{\mathrm{i}} / \mathrm{du}^{\mathrm{B}}=-\left[\rho \alpha_{\mathrm{i}}^{\mathrm{P}}+(1-\rho) \alpha_{\mathrm{i}}^{\mathrm{R}}\right] /\left(\gamma_{\mathrm{i}}^{\mathrm{P}}-\gamma_{\mathrm{i}}^{\mathrm{R}}\right)\left(\partial \rho / \partial \mathrm{p}_{\mathrm{m}}\right)<0$.

(b.3) $\mathrm{dx}_{\mathrm{i}} / \mathrm{du}^{\mathrm{SB}}=\left[\rho\left(1-\alpha_{\mathrm{i}}^{\mathrm{P}}\right)+(1-\rho) \alpha_{\mathrm{i}}^{\mathrm{R}}\right] /\left(\gamma_{\mathrm{i}}^{\mathrm{P}}-\gamma_{\mathrm{i}}^{\mathrm{R}}\right)\left(\partial \rho / \partial \mathrm{p}_{\mathrm{m}}\right)>0$.

(b.4) $\mathrm{dx}_{\mathrm{i}} / \mathrm{du}^{\mathrm{SW}}=\left[\rho \alpha_{\mathrm{i}}^{\mathrm{P}}+(1-\rho)\left(1-\alpha_{\mathrm{i}}^{\mathrm{R}}\right)\right] /\left(\gamma_{\mathrm{i}}^{\mathrm{P}}-\gamma_{\mathrm{i}}^{\mathrm{R}}\right)\left(\partial \rho / \partial \mathrm{p}_{\mathrm{m}}\right)>0$.

(b.5) $\mathrm{dx}_{\mathrm{i}} / \mathrm{du}^{\mathrm{W}}=-\left[\rho\left(1-\alpha_{\mathrm{i}}^{\mathrm{P}}\right)+(1-\rho)\left(1-\alpha_{\mathrm{i}}^{\mathrm{R}}\right)\right] /\left(\gamma_{\mathrm{i}}^{\mathrm{P}}-\gamma_{\mathrm{i}}^{\mathrm{R}}\right)\left(\partial \rho / \partial \mathrm{p}_{\mathrm{m}}\right)<0$.

(b.6) $\mathrm{dx}_{\mathrm{i}} / \mathrm{d} \alpha_{\mathrm{i}}^{\mathrm{P}}=-\rho\left[\mathrm{u}^{\mathrm{B}}-\mathrm{u}^{\mathrm{W}}+\left(\mathrm{u}^{\mathrm{SB}}-\mathrm{u}^{\mathrm{SW}}\right)\right] /\left(\gamma_{\mathrm{i}}^{\mathrm{P}}-\gamma_{\mathrm{i}}^{\mathrm{R}}\right)\left(\partial \rho / \partial \mathrm{p}_{\mathrm{m}}\right)<0$.

(b.7) $\mathrm{dx}_{\mathrm{i}} / \mathrm{d} \alpha_{\mathrm{i}}^{\mathrm{R}}=-(1-\rho)\left[\mathrm{u}^{\mathrm{B}}-\mathrm{u}^{\mathrm{W}}-\left(\mathrm{u}^{\mathrm{SB}}-\mathrm{u}^{\mathrm{SW}}\right)\right] /\left(\gamma_{\mathrm{i}}^{\mathrm{P}}-\gamma_{\mathrm{i}}^{\mathrm{R}}\right)\left(\partial \rho / \partial \mathrm{p}_{\mathrm{m}}\right)<0$.

(b.8) $\mathrm{dx}_{\mathrm{i}} / \mathrm{dk}_{\mathrm{SC}}=1 /\left(\gamma_{\mathrm{i}}^{\mathrm{P}}-\gamma_{\mathrm{i}}^{\mathrm{R}}\right)\left(\partial \rho / \partial \mathrm{p}_{\mathrm{m}}\right)>0$. QED

Proof of Proposition 3'. To see that there cannot be any other type of (pure-strategy) equilibrium, suppose that judge $\mathrm{m}$ does not write a dissenting opinion for a set of $\mathrm{p}_{\mathrm{m}}$-values $\left[0, \mathrm{x}_{\mathrm{m}}\right) \cup\left(\mathrm{x}^{\mathrm{U}}, 1\right]$ plus some additional subset of values $b \subset\left[x_{m}, x^{U}\right]$ (excluding $b=\left\{x_{m}\right\}$ and $b=\left\{x^{U}\right\}$; see footnote 29), and writes for the remaining values of $\mathrm{p}_{\mathrm{m}}$. If all justices would vote to deny cert based on the belief that no opinion came from the set $\left[0, x_{m}\right) \cup\left(x^{U}, 1\right] \cup b$, then judge $m$ has an incentive to defect from not writing to writing for some $\mathrm{p}_{\mathrm{m}} \in \mathrm{b}$, since this will provoke cert ( since $\max _{\mathrm{i}}\left\{\mathrm{V}_{\mathrm{i}}\left(\mathrm{p}_{\mathrm{M}}, \mathrm{p}_{\mathrm{m}}\right)\right\}>0$ for $\left.\mathrm{p}_{\mathrm{m}} \in \mathrm{b}\right)$. On the other hand, if some justice would vote to grant cert based on the belief that no opinion came from the set $\left[0, x_{m}\right) \cup\left(x^{U}, 1\right] \cup b$, then judge $m$ has an incentive to defect from writing to not writing for those values of $\mathrm{p}_{\mathrm{m}} \notin\left[0, \mathrm{x}_{\mathrm{m}}\right) \cup\left(\mathrm{x}^{\mathrm{U}}, 1\right] \cup \mathrm{b}$. Thus, no such writing strategies on the part of judge $m$ can be part of a (pure-strategy) equilibrium.

Proof of part (a). If judge $m$ uses a strategy of writing if and only if $p_{m} \in\left[x_{m}, x^{U}\right]$, then upon observing no opinion, the justices infer that $\mathrm{p}_{\mathrm{m}} \in\left[0, \mathrm{x}_{\mathrm{m}}\right) \cup\left(\mathrm{x}^{\mathrm{U}}, 1\right]$ and calculate $\mathrm{V}_{\mathrm{i}}\left(\mathrm{p}_{\mathrm{M}},\left[0, \mathrm{x}_{\mathrm{m}}\right) \cup\right.$ $\left.\left(\mathrm{x}^{\mathrm{U}}, 1\right]\right)=\mathrm{E}\left\{\mathrm{V}_{\mathrm{i}}\left(\mathrm{p}_{\mathrm{M}}, \mathrm{p}_{\mathrm{m}}\right) \mid \mathrm{p}_{\mathrm{m}} \in\left[0, \mathrm{x}_{\mathrm{m}}\right) \cup\left(\mathrm{x}^{\mathrm{U}}, 1\right]\right\}$. If this is non-positive for all justices (as hypothesized in part (a)), then cert will not be granted without a dissenting opinion. But then it will be optimal for judge $m$ to write if and only if $p_{m} \in\left[x_{m}, x^{U}\right]$, which provokes cert. Thus a Type IIb equilibrium exists under the hypothesis of part (a).

Proof of part (b). If judge $m$ uses a strategy of not writing for any $\mathrm{p}_{\mathrm{m}} \in[0,1]$, then upon observing no opinion, the justices infer that $\mathrm{p}_{\mathrm{m}} \in[0,1]$, and calculate $\mathrm{V}_{\mathrm{i}}\left(\mathrm{p}_{\mathrm{M}},[0,1]\right)$. Under the hypothesis of part (b), $\max _{\mathrm{i}}\left\{\mathrm{V}_{\mathrm{i}}\left(\mathrm{p}_{\mathrm{M}},[0,1]\right)\right\} \geq 0$ so at least one justice will vote to grant cert without an opinion. But then it will be optimal for judge $m$ not to write an opinion for any $p_{m} \in[0,1]$, so a Type I equilibrium exists under the hypothesis of part (b). QED

Proof of Proposition 4. To see that there cannot be any other type of (pure-strategy) equilibrium, suppose that judge $m$ does not write a dissenting opinion for a set of $\mathrm{p}_{\mathrm{m}}$-values $\left[0, \mathrm{x}_{\mathrm{m}}\right) \cup\left(\mathrm{x}^{\mathrm{U}}, \mathrm{x}^{\mathrm{S}}\right)$ plus some additional subset of values $\mathrm{b} \subset\left[\mathrm{x}_{\mathrm{m}}, \mathrm{x}^{\mathrm{U}}\right] \cup\left[\max \left\{\mathrm{x}_{\mathrm{m}}, \mathrm{x}^{\mathrm{S}}\right\}, 1\right]$ (excluding $\mathrm{b}=\left\{\mathrm{x}_{\mathrm{m}}\right\}, \mathrm{b}=\left\{\mathrm{x}^{\mathrm{U}}\right\}$, and $\mathrm{b}=\left\{\max \left\{\mathrm{x}_{\mathrm{m}}, \mathrm{x}^{\mathrm{S}}\right\}\right\}$; see footnotes 26 and 29), and writes for the remaining values of $\mathrm{p}_{\mathrm{m}}$. If all justices would vote to deny cert based on the belief that no opinion came from the set $\left[0, x_{m}\right) \cup\left(x^{U}\right.$, $\left.x^{S}\right) \cup b$, then judge $m$ has an incentive to defect from not writing to writing for some $p_{m} \in b$, since 
this will provoke cert ( since $\max _{\mathrm{k}}\left\{\mathrm{V}_{\mathrm{k}}\left(\mathrm{p}_{\mathrm{M}}, \mathrm{p}_{\mathrm{m}}\right)\right\}>0$ for $\left.\mathrm{p}_{\mathrm{m}} \in \mathrm{b}\right)$. On the other hand, if some justice would vote to grant cert based on the belief that no opinion came from the set $\left[0, x_{m}\right) \cup\left(x^{U}, x^{S}\right) \cup$ $b$, then judge $m$ has an incentive to defect from writing to not writing for those values of $p_{m} \notin[0$, $\left.\mathrm{x}_{\mathrm{m}}\right) \cup\left(\mathrm{x}^{\mathrm{U}}, \mathrm{x}^{\mathrm{S}}\right) \cup \mathrm{b}$. Thus, no such writing strategies on the part of judge $\mathrm{m}$ can be part of a (purestrategy) equilibrium.

Proof of part (a). If judge $m$ uses a strategy of writing if and only if $p_{m} \in\left[x_{m}, x^{U}\right] \cup$ $\left[\max \left\{x_{m}, x^{S}\right\}, 1\right]$, then upon observing no opinion, the justices infer that $p_{m} \in\left[0, x_{m}\right) \cup\left(x^{U}, x^{S}\right)$ and calculate $\mathrm{V}_{\mathrm{k}}\left(\mathrm{p}_{\mathrm{M}},\left[0, \mathrm{x}_{\mathrm{m}}\right) \cup\left(\mathrm{x}^{\mathrm{U}}, \mathrm{x}^{\mathrm{S}}\right)\right)=\mathrm{E}\left\{\mathrm{V}_{\mathrm{k}}\left(\mathrm{p}_{\mathrm{M}}, \mathrm{p}_{\mathrm{m}}\right) \mid \mathrm{p}_{\mathrm{m}} \in\left[0, \mathrm{x}_{\mathrm{m}}\right) \cup\left(\mathrm{x}^{\mathrm{U}}, \mathrm{x}^{\mathrm{S}}\right)\right\}$. If this is non-positive for all justices (as hypothesized in part (a)), then cert will not be granted without a dissenting opinion. But then it will be optimal for judge $m$ to write if and only if $p_{m} \in\left[x_{m}, x^{U}\right] \cup$ $\left[\max \left\{\mathrm{x}_{\mathrm{m}}, \mathrm{x}^{\mathrm{S}}\right\}, 1\right]$, which provokes cert. Thus a Type IIc equilibrium exists under the hypothesis of part (a).

Proof of part (b). If judge $m$ uses a strategy of not writing for any $\mathrm{p}_{\mathrm{m}} \in[0,1]$, then upon observing no opinion, the justices infer that $\mathrm{p}_{\mathrm{m}} \in[0,1]$, and calculate $\mathrm{V}_{\mathrm{k}}\left(\mathrm{p}_{\mathrm{M}},[0,1]\right)$. Under the hypothesis of part (b), $\max _{\mathrm{k}}\left\{\mathrm{V}_{\mathrm{k}}\left(\mathrm{p}_{\mathrm{M}},[0,1]\right)\right\} \geq 0$ so at least one justice will vote to grant cert without an opinion. But then it will be optimal for judge $m$ not to write an opinion for any $p_{m} \in[0,1]$, so a Type I equilibrium exists under the hypothesis of part (b). QED. 